\title{
Isenção Política na Polícia Federal: A AUTONOMIA EM SUAS DIMENSÕES ADMINISTRATIVA, FUNCIONAL E ORÇAMENTÁRIA
}

Guilherme Cunha Werner

Departamento de Polícia Federal - Brasil

$$
\approx
$$

\begin{abstract}
RESUMO
O foco do presente estudo é analisar sob uma perspectiva renovada a importância do reconhecimento da autonomia para o Departamento da Polícia Federal no exercício de sua função constitucional de Polícia Judiciária da União. A partir da análise minuciosa das formas de desconstrução das Instituições no Estado Democrático, sistematizadas em três grupos, quais sejam: apoderamento, usurpação e desestruturação, constrói-se argumentos fortes para fundamentar a necessidade do reconhecimento da autonomia em suas três dimensões: administrativa, funcional e orçamentária - com o fim de buscar o fortalecimento institucional e seu necessário insulamento para ajudar a superar problemas gerados pelas crises política, econômica e ética no Brasil e, assim, garantir uma atuação independente, republicana, eficiente, isenta e imparcial. Ao final, há a apresentação de sugestão de medidas de caráter urgente que devem ser providenciadas para atingir este objetivo.
\end{abstract}

Palavras-Chave: Autonomia. Jurisdicionalidade. Insulamento burocrático. Apoderamento institucional

\section{INTRODUÇÃ̃o}

O presente trabalho tem a finalidade de analisar a importância do Departamento de Polícia Federal como uma instituição constitucionalmente legitimada para desempenhar de forma exclusiva as atribuições de Polícia Judiciária da União, atividade jurídica e de caráter jurisdicional , cuja missão, dentre outras, é promover o combate à corrupção e à criminalidade organizada, mazelas que assolam a muito nosso país, impedem o desenvolvimento social, abalam a livre concorrência, incentivam a má governança e prejudicam os mais vulneráveis. A linha de argumentação adotada parte da constatação de que o bom desempenho dessa missão institucional encontra-se diretamente relacionado com a sua organização de forma autônoma, nos âmbitos administrativo, 
funcional e financeiro, sendo estes os três pilares essenciais para a construção de uma Polícia Judiciária republicana, eficiente, isenta e imparcial.

\section{IDENTIFICAÇÃo dos PERIgOS DA DESCONSTRUÇÃo do Trabalho da Polícia Judiciária da União}

O ponto central de discussão do presente artigo consiste em identificar a retórica oculta no discurso de esvaziamento das atividades de Polícia Judiciária da União, bem como, identificar três fenômenos distintos e historicamente perceptíveis relativos à desconstrução dos órgãos de Estado derivados das deturpações sofridas nos regimes democráticos e republicanos manifestos na forma do apoderamento ${ }^{1}$, usurpação e desestruturação das instituições de Estado, e ao final, apontar a necessidade da criação de uma Polícia Judiciária da União autônoma, eficiente, imparcial, capaz de enfrentar os grandes temas nacionais, especificamente, no combate a corrupção e desvio de verbas públicas, dentre outros, por ser, justamente, uma atividade eminentemente de proteção do regime democrático e da defesa das instituições republicanas.

Os três pontos paradigmas do presente trabalho, o apoderamento, a usurpação e a desestruturação são a antítese da autonomia em suas dimensões administrativa, funcional e orçamentária, respectivamente.

O apoderamento pode ser identificado nas práticas clientelistas de submissão das instituições públicas à vontade particular, com o nascimento de um único corpo obediente às vontades das oligárquicas e dos detentores do poder que se sobrepõe ao interesse público, no outro extremo, do mesmo fenômeno, encontramos a forma ditatorial observável nos regimes totalitários onde as instituições se encontram submetidas à vontade do ditador ou líder supremo, com manifestações deturpadas do exercício do poder e da boa governança.

A usurpação é identificável na invasão de atribuição por outros órgãos não autorizados que passam a realizar tarefas exclusivas de outras instituições legalmente constituídas, em patente desrespeito ao desenho constitucional. Instala-se um cenário onde a incerteza e a insegurança jurídica tornam-se a força motriz da injustiça, pondo em risco as atividades de Estado. $\mathrm{O}$ cenário

1 O termo apoderamento, aqui utilizado, explicita a forma ilícita da tomada do comando e da decisão na condução de determinada atividade das mãos da autoridade que a legitimamente detém como observável no apoderamento ilícito de aeronaves, onde terroristas tomam o controle da aeronave das mãos de seu comandante para praticarem atos criminosos. 
agrava-se quando atinge atividades relacionadas às investigações criminais realizadas por instituições que não detêm autorização legal para tal finalidade, com a institucionalização da impunidade ${ }^{2}$.

A desconstrução apresenta um forte viés instrumental e é identificável na desestruturação institucional por meio de instrumentos econômicos de controle orçamentário, contingenciamento de recursos ou fixação dos índices em patamares inferiores aos níveis inflacionários, com a inviabilização da manutenção e investimentos no aprimoramento, desenvolvimento e inovação, tanto da própria instituição, quanto da capacitação técnico-profissional, com abalo na eficiência e qualidade da prestação dos serviços públicos.

\section{AUTONOMIA: DIMENSÃo E RELEVÂNCIA}

A compreensão da relevância da autonomia, em suas dimensões administrativa, funcional e financeira, como pilar de sustentação de uma Polícia Judiciária eficiente, imparcial, de caráter republicano, capaz de atender aos preceitos democráticos e as demandas institucionais, especificamente no combate a corrupção e desvio de verbas públicas, necessita de uma previa contextualização histórica.

Inicialmente, identifica-se no debate político contemporâneo uma aparente dicotomia entre a realização da Democracia e o exercício da República, concepções de dimensões distintas e de convivência árdua. A democracia é caracterizada pela inclusão política e social, enquanto a república é o governo da lei voltado ao bem comum, eficaz e transparente, assim:

As democracias podem não ser republicanas, como as democracias socialistas, e as repúblicas podem não ser democráticas, como a romana não o foi. Uma das maneiras de caracterizar o momento político atual vivido pelo Brasil é dizer que precisamos continuar a democratizar a república pela inclusão social, sem abandonar o esforço de republicanizar a democracia pelo governo eficaz e transparente, requisito indispensável parta o fortalecimento das instituições. (CARVALHO, 2014, p. 245)

2 O Departamento de Polícia Federal tem o dever funcional de apurar infrações penais contra a ordem política e social ou em detrimento de bens, serviços e interesses da União ou de suas entidades autárquicas e empresas públicas exercendo com exclusividade a Polícia Judiciária da União conforme determina o artigo $144 \$ 1^{\circ}$ incisos I e IV da Constituição Federal. - Não está na doutrina ou na jurisprudência, nem na ilação, e muito menos na emoção, está escrito de forma expressa na Constituição e portanto, deve ser cumprido. 
No Brasil, o Departamento de Polícia Federal insere-se no contexto político nacional, tanto como órgão de Estado destinado a defesa da democracia manifesta no respeito às Liberdades Públicas, Direitos Humanos e no Estado Democrático de Direito, quanto na defesa das instituições de Estado, patrimônio da União, Sistema Financeiro Nacional, dentre outras atividades eminentemente de salvaguarda da república.

Para cumprir com sua missão é determinante ter uma boa organização e estrutura de forma a garantir o necessário grau de independência, autonomia administrativa e conferir a seus integrantes garantias específicas para o exercício pleno de suas funções constitucionais de Polícia Judiciária da União.

A autonomia é identificada na regra geral de outorga da legitimidade pela sociedade durante a criação legislativa, neste sentido, a Autoridade Policial é investida das prerrogativas do seu cargo e designada a decidir dentro dos estritos balizamentos legais. Suas decisões são de cunho jurisdicional ${ }^{3}$ uma vez que, ao decidir aplica as normas legais, subsumindo-as ao caso concreto, as decisões proferidas encontram duplo suporte nos conhecimentos jurídico-legais e nas habilidades e experiências técnico-profissionais.

Portanto, as decisões de autoridade emanam de atos fundamentados no estrito cumprimento da lei e não podem, e não devem de forma alguma, estarem maculados ou onerados por demandas externas ou desejos particulares.

A ausência de autonomia dificulta a correta aplicação da lei e impede o legítimo desenvolvimento das atividades de Polícia Judiciária, com o perigo de transformá-la em um instrumento a serviço dos detentores do poder, incapacitando-a do pleno exercício de suas funções constitucionalmente atribuídas. Assim, a necessária manutenção da isenção política na Polícia Federal funda-se em três dimensões da autonomia, quais sejam:

Administrativa: prerrogativa legal do administrador de disciplinar no plano interno as atividades legais através dos instrumentos normativos de auto-organização.

Funcional: confere a prerrogativa de dar cumprimento à lei e adotar as medidas necessárias para o exato desempenho de suas funções,

3 O Delegado de Polícia aplica a norma penal ao caso concreto ao decidir sobre a prisão em flagrante, fixar valores de fianças, expedir alvarás de soltura, formalizar o indiciamento, concluir o Inquérito Policial com a indicação de autoria ou opinando pelo arquivamento do mesmo caso seja apurado que não houve crime, tais exemplos serão retomados adiante. 
não podendo sofrer influências, tanto no plano externo, quando no plano interno, do exercício de suas atribuições legais, sendo oponíveis inclusive contra outros órgãos e poderes públicos e políticos da federação.

Orçamentária: manifesta no pleno exercício das capacidades de iniciativa e elaboração de sua proposta de custeio dentro dos limites estabelecidos em lei.

São três prerrogativas institucionais necessárias e indispensáveis. Encontram-se inseridas na agenda política nacional, no debate público e espelham os anseios de desejos que a "sociedade espera da Polícia Federal no exercício de suas funções institucionais com imparcialidade e efetividade", conforme consta na justificativa da Proposta de Ementa Constitucional PEC n. ${ }^{\circ}$ $412 / 2009$, com texto de alteração do $\$ 10^{\circ}$ do art. 144 da constituição com a seguinte redação:

Art. $144[\ldots]$

$\$ 1^{\circ}$. Lei Complementar organizará a polícia federal e prescreverá normas para a sua autonomia funcional e administrativa e a iniciativa de elaborar sua proposta orçamentária dentro dos limites estabelecidos na lei de diretrizes orçamentárias, com as seguintes funçôes institucionais.

O fundamento da propositura ainda apresenta os seguintes argumentos:

Outro fenômeno negativo derivado dessa desatenção com a Polícia Federal é a usurpação das funções constitucionais de Policia Judiciária da União por parte de órgãos policiais de patrulhamento rodoviário, militares estaduais e até por órgãos não policiais em absoluto e frontal desrespeito a Magna Carta, sob o argumento de "ocupação de espaço institucional".

[...]

Por fim, não se está aqui propondo uma Polícia Federal independente. Não se pode confundir autonomia gerencial com independência funcional absoluta, vez que ela só existe no nivel técnico.

A Polícia Federal continuará submetida ao controle finalístico do Ministério da Justiça, a quem continuará vinculado, aos órgãos de controle da União tais como CGU e TCU, ao controle externo da atividade policial pelo Ministério Público e ao controle jurisdicional dos órgãos do Poder Judiciário, sem prejuizo da criação da Ouvidoria das Polícias da União. 
Deixar de investir na Polícia Federal, é deixar de investir no combate à criminalidade, à corrupção e à impunidade no pais. Perde a sociedade brasileira.

A proposta recebeu parecer favorável de admissibilidade da Comissão de Constituição e Justiça e de Cidadania da Câmara dos Deputados, destacando-se os seguintes fundamentos:

Para tanto, é importante que a Instituição tenha autonomia, tanto funcional, quanto administrativa, podendo elaborar sua proposta orçamentária. Tal "status" constitucional vai garantir à Polícia Federal a condição de Órgão de Estado, e não mais de Governo, com todas as benéficas consequências dessa nova situação para o eficaz e isento exercício da sua nobre missão. A aprovação da presente proposta, portanto, constituir-se-á em passo decisivo e necessário rumo ao aperfeiçoamento do Estado Democrático de Direito no Brasil, assim como medida importantissima para o efetivo enfrentamento da criminalidade.

Apesar dos sólidos fundamentos apresentados, respaldados pelos anseios e desejos da sociedade brasileira, faz-se necessário identificar a retórica oculta no discurso fisiológico-partidário de cunho corporativista de algumas instituições na busca pela desconstrução da atividade de Polícia Judiciária da União constitucionalmente atribuída ao Departamento de Polícia Federal.

Destaco finalmente que a autonomia é recomendada no plano internacional conforme disposto na Convenção das Nações Unidas Contra o Crime Organizado Transnacional - Convenção de Palermo (Decreto n. ${ }^{\circ}$ 5.015/2004 art. 9 1 e 2), e na Convenção das Nações Unidas Contra a Corrupção - Convenção de Mérida (Decreto n. ${ }^{\circ}$ 5.687/2006 art. 6, 11 e 36), que estabeleceram o dever dos Estados Parte em adotar medidas eficazes de ordem legislativa e administrativa visando promover a integridade, prevenir, detectar e punir a corrupção dos agentes públicos bem como adote medidas no sentido de se assegurar que as suas autoridades que atuam em matéria de prevenção, detecção e repressão da corrupção de agentes públicos, possa agir de maneira eficaz inclusivamente conferindo a essas autoridades independência suficiente para impedir qualquer influência indevida sobre a sua atuação. 


\section{Retórica da DesconstruÇão: O CORPORATIVISMO EXACERBADO}

O discurso contrário à autonomia da Polícia Judiciária da União é uma constante do corporativismo de outras instituições, caminha na contramão da história, contraria a conjuntura atual da realidade brasileira, nega todo o seu contexto político, esquece sua formação social, oculta interesses, implicações econômicas e fortalece a impunidade.

Como exemplo de tal corporativismo exacerbado destaco dois documentos produzidos pelo Ministério Público Federal, o primeiro é a Nota Técnica n. ${ }^{\circ}$ 4, de 14 de Abril de 2015, da 7. . Câmara de Coordenação e Revisão (Controle Externo da Atividade Policial e Sistema Prisional) da Procuradoria Geral da República ${ }^{4}$, que afirma:

2. DA PRETENDIDA INDEPENDÊNCIA DA POLÍCIA FEDERAL

$[\ldots]$

"Tal proposta levaria à criação de um perigoso rompimento do equilibrio entre os órgãos de poder, conferindo poderes exacerbados a um braço armado do Estado, com previsiveis consequências nefastas ao próprio Estado Democrático de Direito e aos direitos fundamentais dos cidadãos.

A policia é órgão estatal que representa o emprego da violência estatal no seio da sociedade. Atividade de inegável importância, mas que, por imperativo democrático, deve ser submetido a controles rigorosos, na defesa dos direitos fundamentais do cidadão. Não à toa, a Constituição conferiu ao Ministério Público o controle externo da atividade policial, cujo fundamento mais essencial é a proteção dos direitos fundamentais, exercendo importante papel no sistema de freios e contrapesos entre os órgãos de poder.

Ademais, não se deve perder de vista que o texto original da PEC 412/2009 prevê independência apenas para a Policia Federal, porém nada impede, ao contrário, incentivo haverá, para que todas as forças policiais reivindiquem autonomia nos mesmos moldes. Estamos a falar das Policias Civis e Militares dos Estados.

[...]

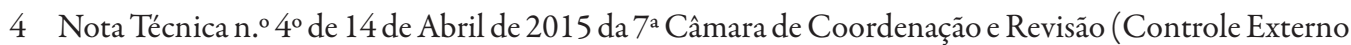
da Atividade Policial e Sistema Prisional) da Procuradoria Geral da República em: http://7ccr.pgr. mpf.mp.br/notastecnicas/NT7CCRn4de14deabrilde2015.pdf/view Visitado em 11.06.2015. 
Para melhor se vislumbrar o despautério da proposta, considere-se a hipótese de concessão de semelhante "autonomia funcional, administrativa e orçamentária" às Forças Armadas. A situação seria análoga, certo que tanto as Forças Armadas quanto a Policia representam os braços armados do Estado. Pretender retirar virtualmente tais órgãos da esfera do Poder Executivo, dando-lhes autonomia, implicaria em verdadeiro atentado ao Estado Democrático de Direito.

[...]

Impende considerar, portanto, que conferir autonomia funcional, administrativa e orçamentária à Polícia corresponde a trilhar-se um perigoso caminho de enfraquecimento dos controles sobre o braço armado do Estado, seja pelo viés da condução de politicas públicas pelo Poder Executivo, seja pelo viés do controle externo da atividade policial, exercido pelo Ministério Público (art. 129, inc. VIl da CF).

O segundo documento é o Parecer n. ${ }^{\circ}$ 4.330/2015-AsJConst/SAJ/ PGR da Procuradoria-Geral da República, na Ação Direta de Inconstitucionalidade ADI n. ${ }^{0} 5.073 / \mathrm{DF}$, insurgindo-se contra a Lei n. ${ }^{\circ}$ 12.830/2013, referente à investigação criminal conduzida por Delegado de Polícia, dos quais se destacam os seguintes argumentos 5 :

As atividades exercidas por delegado de policia, ou seja, apuração de infração penal e funções de polícia criminal, em decorrência dos comandos constitucionais, possuem natureza eminentemente administrativa, não jurídica, a despeito de envolverem elementos jurídicos, como diversas outras funçôes públicas de natureza administrativa. (g.n.)

$[\ldots]$

Atribuir status jurídico às funçôes de delegado de polícia importa aproximação indevida, descabida, dessa função com a de cargos como os de juiz, membro do Ministério Público e advogado (incluido o defensor público), estes de natureza eminentemente jurídica. Causa também distanciamento indesejável desse cargo da carreira policial, o que é prejudicial ao curso das investigações criminais, sobretudo em pais como o Brasil, cujo modelo de inquérito policial é extremamente ineficiente, burocrático e bacharelesco, em mimetismo desnecessário, redundante, do processo judicial, no qual frequentemente delegados de polícia emulam a atuação do Ministério Público e do Judiciário. (g.n.)

5 Manifestação da Procuradoria-Geral da República Parecer n. ${ }^{\circ}$ 4.330/2015-AsJConst/SAJ/PGR Ação Direta de Inconstitucionalidade ADI n. 5073 do Supremo Tribunal Federal disponível em: http://www.stf.jus.br/portal/processo/verProcessoAndamento.asp ?incidente $=4507489$ consultado em 15.06.2015. 
A retórica constatada nos discursos destacados apresenta como único objetivo a desconstrução das atividades de Polícia Judiciária da União como expressão de função republicana do Estado Democrático de Direito ao apresentar, dentre tantos argumentos falsos e falaciosos, a afirmação de que "A polícia é órgão estatal que representa o emprego da violência estatal no seio da sociedade.", incutindo a falsa conclusão que a polícia usa a violência contra a sociedade.

Para melhor compreender a falácia dos argumentos apresentados, faz-se necessário identificar e esclarecer o papel que a Polícia Judiciária ocupa no Estado Democrático de Direito e seu fundamento histórico na construção da democracia republicana.

O Estado exerce o uso legítimo da força e não da violência, uma vez que a violência pressupõe uma ação contrária a ordem moral, jurídica ou política, portanto, afirmar que o poder político estatal exerce o monopólio legítimo da violência é afirmar que, a violência é o meio específico e exclusivo, para o exercício do poder político, sendo este contrário a lei; portanto uma ação de Estado legitima deve desenvolver-se dentro dos estritos balizamentos legais e não pode nunca ser desempenhada como uma pretensão de exercício ilimitado da vontade dos governantes.

Trata-se de uma deturpação, ou na melhor das hipóteses, uma má tradução, do texto de Max Weber cujo título é "A Política Como Vocação" (Politik als Beruf) publicado em 1919, na qual o autor se propóe a delinear o Estado moderno como uma associação política contrapondo-se de forma critica à celebre afirmação de Trotsky proferida durante o discurso de Brest-Litovsk, ao afirmar que "cada Estado é fundado sobre a violência"6.

O modelo de Estado Weberiano é definido como a comunidade humana inserida em um determinado território - caracterizada pelo monopólio do uso legítimo da força física ${ }^{7}$, sendo este uso desempenhado

6 No texto original: Man kann vielmehr den modernen Staat soziologisch letztlich nur definieren aus einem spezifischen Mittel, das ihm, wie jedem politischen Verband, eignet: der physischen Gewaltsamkeit. "Jeder Staat wird auf Gewalt gegründet", sagte seinerzeit Trotzky in Brest-Litowsk. (WEBER, 1999, pp. 369-370)

7 A edição brasileira do livro de Max Weber Wissenschaft Als Berufe Politik Als Beluf editado como Ciência e Política duas Vocações, apresenta a seguinte tradução: "o Estado contemporâneo como uma comunidade humana que, dentro dos limites de determinado território - a noção de território corresponde a um dos elementos essenciais do Estado - reivindica o monopólio do uso legitimo da 
por meio das instituições legal, legitimamente constituídas e detentoras de atribuições legais para fazer ou não uso da força física, destinada a vencer toda a conduta que seja contrária à lei, exercendo-a apenas e exclusivamente através das instituições de Estado designadas para tal finalidade (WEBER, 2008, pp 56-57).

O legítimo balizamento da atuação do Estado decorre do pactuado através das leis, não sendo legítima a ação estatal baseada na violência. A afirmação de que o Estado detém o monopólio do uso legítimo da violência não pode - e não deve - ser considerada correta, em razão inclusive da imprecisão no uso dos conceitos, por si só antagônicos - violência e força-, sendo o Estado a fonte de legitimação do exercício da força, compreendida como a coação física utilizável em última instância para vencer a violência e, assim, reestabelecer a ordem pública e a paz social em benefício de todos os cidadãos. ${ }^{8}$

Corroborando essa imprecisão técnica na retórica da desconstrução identificamos a tendência de igualar várias instituições, com finalidades distintas, em um mesmo rol de atribuições como Polícia Militar, Policial Civil e Exército Brasileiro, instituições denominadas de braço armado do estado conforme descrito no Parecer n. ${ }^{\circ}$ 4.330/2015-AsJConst/SAJ/PGR da Procuradoria-Geral da República, assim destaco:

Ademais, não se deve perder de vista que o texto original da PEC 412/2009 prevê independência apenas para a Polícia Federal, porém nada impede, ao contrário, incentivo haverá, para que todas as forças policiais reivindiquem autonomia nos mesmos moldes. Estamos a falar das Policias Civis e Militares dos Estados.

Para melhor se vislumbrar o despautério da proposta, considere-se a hipótese de concessão de semelhante "autonomia funcional, administrativa e orçamentária" às Forças Armadas. A situação seria análoga, certo que tanto as Forças Armadas quanto a Policia representam

violência física" (Weber, 2011, p. 56), e no texto original: Heute dagegen werden wir sagen müssen: Staat ist diejenige menschliche Gemeinschaft, welche innerhalb eines bestimmten Gebietes - dies: das "Gebiet" gehört zum Merkmal - das Monopol legitim er physischer Gewaltsamkeit für sich (mit Erfolg) beansprucht. (monopólio legítimo do uso da força) (WEBER, 1999: 369-370)

8 Nessa linha de argumentação e utilizando-se do mesmo arcabouço teórico, destaco as conclusões do VIII Congresso das Nações Unidas sobre a Prevenção do Crime e o Tratamento dos Delinquentes das Nações Unidas, de 7 de setembro de 1990, onde foram estabelecidos os Princípios Básicos Sobre o Uso da Força e Armas de Fogo pelos Funcionários Responsáveis pela Aplicação da Lei; assim o uso legítimo da força deve ser exercido com moderação e na exata medida e proporção da gravidade da infração em consonância com o objetivo legítimo a ser atingido, com o escopo de minimizar os danos e ferimentos e respeitar e preservar a vida humana (UNITED NATIONS CCPCJ, 1990). 
os braços armados do Estado. Pretender retirar virtualmente tais órgãos da esfera do Poder Executivo, dando-lhes autonomia, implicaria em verdadeiro atentado ao Estado Democrático de Direito.

Com efeito, não se pode vislumbrar qualquer possibilidade de que as instituiçôes policiais tornem-se independentes e autônomas, pois isso não condiz com os conceitos de democracia e república. Não há exemplo histórico de democracia que tenha sobrevivido intacta quando Forças Armadas ou policias tenham se desvinculado de controles. Em suma, não há democracia com braço armado autônomo e independente.

A narrativa apresentada confunde conceitos de "segurança" e "defesa”, bem como, os órgãos de Estado com atribuições constitucionais distintas. Assim, se por um lado, a garantia da ordem pública e da paz social é feita por meio de instrumentos de segurança pública, desempenhada pelas instituições policiais, do outro lado, temos os órgãos de defesa, salvaguarda e manutenção da soberania nacional, assim como, da integridade do seu território contra as ameaças externas, cujas atividades são realizáveis por meio dos instrumentos de defesa específicos das Forças Armadas. É nítida a confusão conceitual apresentada ao misturar instrumentos de segurança com defesa, atuação interna com externa, atividades de Estado com as atividades dos Estados Federativos no que tange as polícias civis e militares dos entes federados.

A incorreção é tamanha, que não pode ser atribuído ao desconhecimento dos papeis e atribuições constitucionais das instituições de Estado, trata-se de um discurso que oculta uma retórica sustentada apenas em uma narrativa profética, cujo objetivo final é de se apresentar ao leitor como derradeiro herói da defesa e da salvação nacional.

A essência do discurso identificado, tanto no parecer, quanto na nota técnica, remonta à estratégia totalitária de desconstrução da legitimidade constitucional de órgãos de Estado, observável em outros momentos históricos, como por exemplo, cita-se passagem analisada por Arendt:

A propaganda totalitária aperfeiçoou o cientificismo ideológico e a técnica de afirmações proféticas a um ponto antes ignorado de eficiência metódica e absurdo de conteúdo porque, do ponto de vista demagógico, a melhor maneira de evitar discussão é tornar o argumento independente de verificação no presente e afirmar que só o futuro lhe revelará os méritos (ARENDT, 2000, p. 395) 
Argumentos corporativistas objetivam incutir a falsa percepção de uma realidade deturpada que atende apenas a quem a idealiza. Afirmações de que a autonomia da Polícia Federal levaria a consequências nefastas ao próprio Estado Democrático de Direito e aos direitos fundamentais dos cidadãos ${ }^{9}$ desconstrói a atividade constitucional de Polícia Judiciária da União, o que se torna explicito na afirmação de que o modelo de inquérito policial é extremamente ineficiente, burocrático e bacharelesco, em mimetismo desnecessário, redundante, do processo judicial ${ }^{10}$, com claro conteúdo de desconstrução desprovido de argumentação jurídica.

O inquérito policial não pode ser considerado redundante, uma vez que é anterior e base do processo judicial, sendo instrumento de garantia da segurança jurídica de toda a sociedade e o momento adequado para o investigado apresenta sua defesa e produzir provas.

Nesse sentido, a Exposição de Motivos do Código de Processo Penal, o Decreto-Lei n. ${ }^{\circ}$ 3.689/1914 de 3 de outubro, manteve o Inquérito Policial como processo preliminar e preparatório da ação penal, de natureza contraditória, devendo ser conduzido de forma imparcial para não prejudicar a colheita da prova e inviabilizar futuro processo penal e foi recepcionada pela Constituição Federal de 1988, no contexto do contraditório e devido processo legal, assim:

\section{A Conservação do Inquérito Policial:}

$I V$ - Foi mantido o inquérito policial como processo preliminar ou preparatório da ação penal, guardadas as suas caracteristicas atuais.

[...] há em favor do inquérito policial, como instrução provisória antecedendo a propositura da ação penal, um argumento dificilmente contestável: é ele uma garantia contra apressados e errôneos juizos, formados quando ainda persiste a trepidação moral causada pelo criาme ou antes que seja possivel uma exata visão do conjunto dos fatos, nas suas circunstâncias objetivas e subjetivas. Por mais perspicaz e circunspeta, a autoridade que dirige a investigação inicial, quando ainda perdura o alarma provocado pelo crime, está sujeita

9 Nota Técnica n. 4 $^{\circ}$ de 14 de Abril de 2015 da $7^{\text {a }}$ Câmara de Coordenação e Revisão (Controle Externo da Atividade Policial e Sistema Prisional) da Procuradoria Geral da República em: http://7ccr.pgr. mpf.mp.br/notastecnicas/NT7CCRn4de14deabrilde2015.pdf/view Visitado em 11.06.2015.

10 Manifestação da Procuradoria-Geral da República Parecer n. ${ }^{\circ} 4.330 / 2015$-AsJConst/SAJ/PGR Ação Direta de Inconstitucionalidade ADI n. 5073 do Supremo Tribunal Federal disponível em: http://www.stf.jus.br/portal/processo/verProcessoAndamento.asp ?incidente $=4507489$ consultado em 15.06.2015. 
a equivocos ou falsos juizos a priori, ou a sugestôes tendenciosas. Não raro, épreciso voltar atrás, refa $\neg$ zer tudo, para que a investigação se oriente no rumo certo, até então despercebido. Por que, então, abolir-se o inquérito preliminar ou instrução provisória, expondo-se a justiça criminal aos azares do detetivismo, as marchas e contramarchas de uma instrução imediata e única? Pode ser mais expedito o sistema da unidade de instrução, mas o nosso sistema tradicional, com o inquérito preparatório, assegura uma justiça menos aleatória, mais prudente e serena. (g.n.)

A Constituição Federal de $1988^{11}$ não apenas recepcionou e fortaleceu o caráter processual, jurisdicional e contraditório do Inquérito Policial, como também trouxe novas garantias a ampla defesa especificamente em seus incisos LIV, LV, LXIII e LXIV e reforçou o caráter contraditório do Inquérito Policial ao determinar a necessária participação de advogado em tais atos, o que foi reforçado em 1994, através do Estatuto da Advocacia e a Ordem dos Advogados do Brasil $(\mathrm{OAB})^{12}$, bem como com o advento da Lei n. ${ }^{\circ}$ 11.449/2007, que ao modificar o artigo 306 do Código de Processo Penal, determinou a comunicação da prisão em flagrante de indiciado for hipossuficiente à Defensoria Pública.

Cumpre destacar que o contraditório em alguns casos é realizado no ato do indiciamento, onde é efetuada a qualificação e interrogatório ${ }^{13}$, opor-

11 Constituição Federal 1967 previa entre os Direitos e Garantias Individuais Art. $150 \$ 12$. Ninguém será preso senão em flagrante delito ou por ordem escrita de autoridade competente. A lei disporá sôbre a prestação de fiança. A prisão ou detenção de qualquer pessoa será imediatamente comunicada ao Juiz competente, que a relaxará, se não fôr legal. Por seu turno a Constituição Federal de 1988 no Capítulo I Dos Direitos e Garantias Fundamentais estabelece no Art. $5^{\circ}$ incisos LIV - ninguém será privado da liberdade ou de seus bens sem o devido processo legal; LV - aos litigantes, em processo judicial ou administrativo, e aos acusados em geral são assegurados o contraditório e ampla defesa, com os meios e recursos a ela inerentes; LXIII - o preso será informado de seus direitos, entre os quais o de permanecer calado, sendo-lhe assegurada a assistência da família e de advogado; e no inciso LXIV - o preso tem direito à identificação dos responsáveis por sua prisão ou por seu interrogatório policial.

12 Estatuto da Advocacia e a Ordem dos Advogados do Brasil - OAB (Lei n. 8.906, de 04 de julho de 1994) dispões dobre os direitos dos advogados no Art. $7^{\circ}$ inciso XIV - examinar em qualquer repartição policial, mesmo sem procuração, autos de flagrante e de inquérito, findos ou em andamento, ainda que conclusos à autoridade, podendo copiar peças e tomar apontamentos.

$13 \mathrm{O}$ interrogatório no indiciamento segue o rito estabelecido no artigo $187 \S 1^{\mathrm{a}} \mathrm{e} 2^{\mathrm{o}} \mathrm{e}$ incisos do Código de Processo Penal com a redação atual dada pela Lei n. ${ }^{\circ}$ 10.792/2003, sendo-lhe perguntado: I - ser verdadeira a acusação que lhe é feita; II - não sendo verdadeira a acusação, se tem algum motivo particular a que atribuí-la, se conhece a pessoa ou pessoas a quem deva ser imputada a prática do crime, e quais sejam, e se com elas esteve antes da prática da infração ou depois dela; III - onde estava ao tempo em que foi cometida a infração e se teve notícia desta; IV - as provas já apuradas; V - se conhece as vítimas e testemunhas já inquiridas ou por inquirir, e desde quando, e se tem o que alegar contra elas; VI - se conhece o instrumento com que foi praticada a infração, ou qualquer objeto que com esta se relacione e tenha sido apreendido; VII - todos os demais fatos e pormenores que conduzam à elucidação dos antecedentes e circunstâncias da infração; e VIII - se tem algo mais a alegar em sua defesa. 
tunidade em que o investigado no ato de seu interrogatório toma conhecimento de tudo que foi apurado e apresenta sua defesa, produz provas e indica testemunhas, tratando-se, neste caso, do contraditório diferido ${ }^{14}$, sendo certo que a doutrina destaca tal importância:

$O$ inquérito policial traz elementos que não apenas informam, mas de fato instruem, convencem tais como as declarações de vitimas, os depoimentos das testemunhas, as declaraçóes dos acusados, a acareação, o reconhecimento, o conteúdo de determinados documentos juntados aos autos, as pericias em geral (exames, vistorias e avaliações), a identificação dactiloscópica, o estudo da vida pregressa, a reconstituição do crime. Assim, não é senão em consequência do inquérito que se conserva alguém preso em flagrante: que a prisão preventiva será decretada, em qualquer fase dele, mediante representação da autoridade policial, quando houver prova da existência de crime e indícios suficientes da autoria, e como garantia da ordem pública, conveniência da instrução criminal ou para assegurar a aplicação da lei penal; que à autoridade cumpre averiguar a vida pregressa do indiciado, resultando dessa providência, como é sabido, sensiveis repercussões na graduação da pena." (SAAD, 2004, p. 35)

A matéria atualmente encontra-se pacificada com o posicionamento do Supremo Tribunal Federal o qual ao se manifestou a respeito do tema da editando o seguinte entendimento sumulado:

Súmula Vinculante $n^{\circ} 14$ - É direito do defensor, no interesse do representado, ter acesso amplo aos elementos de prova que, já documentados em procedimento investigatório realizado por órgão com competência de polícia judiciária, digam respeito ao exercício do direito de defesa.

14 Jurisprudência STF Princípio do contraditório e inquérito policial: "O inquérito não possui contraditório, mas as medidas invasivas deferidas judicialmente devem se submeter a esse princípio, e a sua subtração acarreta nulidade. Obviamente não é possível falar-se em contraditório absoluto quando se trata de medidas invasivas e redutoras da privacidade. Ao investigado não é dado conhecer previamente - sequer de forma concomitante - os fundamentos da medida que lhe restringe a privacidade. Intimar o investigado da decisão de quebra de sigilo telefônico tornaria inócua a decisão. Contudo, isso não significa a ineficácia do princípio do contraditório. Com efeito, cessada a medida, e reunidas as provas colhidas por esse meio, o investigado deve ter acesso ao que foi produzido, nos termos da Súmula Vinculante $n^{\circ} 14$. Os fundamentos da decisão que deferiu a escuta telefônica, além das decisões posteriores que mantiveram o monitoramento devem estar acessíveis à parte investigada no momento de análise da denúncia e não podem ser subtraídas da Corte, que se vê tolhida na sua função de apreciar a existência de justa causa da ação penal. Tratase de um contraditório diferido, que permite ao cidadão exercer um controle sobre as invasões de privacidade operadas pelo Estado." (Inq 2266, Relator Ministro Gilmar Mendes, Tribunal Pleno, julgamento em 26.5.2011, DJe de 13.3.2012). 
Assim o Inquérito Policial é o instrumento de garantia que assegura ao investigado: a) a certeza de não ser, a princípio, apontado como autor de um delito sem que o seja; b) a estabilidade das normas a serem seguidas durante a investigação; c) a previsibilidade de não serem desrespeitados os seus direitos fundamentais, eis que as diligências adotadas devem ser registradas; e direta ou indiretamente apresenta as seguintes características e finalidades: c.1.) servir de antecipação probatória prévia do processo penal, seja se pres-tando à acusação ou ao arquivamento da investigação, evitando-se injustiças; c.2.) reconstituir o fato investigado e coletar provas de efeito absoluto e relativo; c.3.) garantir a aplicação da lei penal e das ordens pública e econômica; d) possibilitar a reparação do dano; e c.4.) possibilitar a formulação da defesa. (DAURA E MELO, 2011, pp 111-139).

A atual interpretação do Ministério Público Federal é deturpada e não representa uma atualização do instituto do Inquérito Policial no âmbito das garantias constitucionais do devido processo legal e do contraditório, mas sim, significa a desconsideração de um instrumento historicamente construído juntamente com a instituição da Polícia Judiciária.

O povo reunido deliberou sobre a superação da ignorância, do esquecimento e do desprezo dos governantes pelos direitos do homem, causa dos males públicos e da corrupção dos Governos e declaram solenemente os direitos inalienáveis e sagrados do homem fundados em princípios simples e incontestáveis, na busca pela felicidade geral, assim nasce a Declaração dos Direitos do Homem e do Cidadão, oriunda da Revolução Francesa de 1789, prevendo especificamente duas cláusulas de fundamentais para o garantia dos direitos humanos, quais sejam:

Art. 12 - A garantia dos direitos do homem e do cidadão necessita de uma força pública. Esta força é, pois, instituida para fruição por todos, e não para utilidade particular daqueles a quem é confiada.

Art. 13 - Para a manutenção da força pública e para as despesas de administração é indispensável uma contribuição comum que deve ser dividida entre os cidadãos de acordo com suas possibilidades.

Diante da comoção social e da necessidade de superação foram estabelecidos dois pilares da atividade policial, o primeiro na possibilidade de ação em nome de todos e não apenas a serviço de interesse particular específico, e o segundo na independência orçamentária, dimensões da isenção política. 
No mesmo momento histórico, surge o Código dos Delitos e Das Penas editado na França em 1795 por meio da Lei de 3 do Brumário do Ano IV que estabeleceu:

A polícia é instituida para manter a ordem e a tranquilidade pública,
a liberdade, a propriedade, a segurança individual (...). A polícia ad-
ministrativa tem por objeto a manutenção habitual da ordem pública
em cada lugar e em cada parte da Administração geral. Seu principal
e prevenir delitos. Ela manda executar as leis, ordenaçóes e regula-
mentos de ordem pública. (...) A polícia judiciária investiga os delitos,
os crimes e as contrataçöes que a polícia administrativa não conseguiu
impedir de cometer, reúne provas e entrega autores aos tribunais en-
carregados pela lei de puni-los." (MONET, 2002, p. 104)

Inserido nesse contexto histórico, a Polícia Judiciária nasce com a função jurisdicional de apurar os delitos e identificar seus autores, estando o Delegado de Polícia a cargo das atividades de coordenar e executar as medidas investigativas destinadas a coletar elementos aptos a comprovarem a autoria e materialidade delitiva, sendo tal atividade distinta da atividade de polícia administrativa.

Para persecução de importante finalidade, o Delegado de Polícia é a Autoridade Policial designada por lei responsável pela presidência do Inquérito Policial, neste contexto, pratica atos jurisdicionais de decisão, destacando-se as medidas constritivas de direito como a apreensão de objetos, a requisição da realização de exames periciais, indiciamentos, conduções coercitivas, conforme podemos observar do imperativo legal nos artigos $4^{\circ}$ e seguintes do Código de Processo Penal, e em especial, na Portaria no 523 de 28 de Julho de 1989, Anexo I, no âmbito da Polícia Judiciária da União, ao descrever as atividades do Delegado de Polícia Federal ${ }^{15}$ (WERNER, 2013, p. 179).

15 A Autoridade Policial, em razão de seu poder decisório, recebe tratamento específico, conforme determinado no artigo 39. $\S 1^{\circ}$ inciso I da Constituição Federal, ao fixar os padrões de vencimento do Serviço Público em razão da natureza, grau de responsabilidade e complexidade das atividades desenvolvidas por seus servidores, diferencia-se desta forma o Delgado de Polícia Federal de todos os outros policiais e Agentes da Autoridade nos termos da Lei n. ${ }^{\circ}$ 9.266/1996 de 15 de Março, que estabelece o plano de carreiras do Departamento de Polícia Federal. A Lei n. ${ }^{\circ}$ 13.047/2014 de 2 de Dezembro, inseriu o artigo $2^{\circ}$-A e parágrafo único na Lei n. ${ }^{\circ}$ 9.266/1996 de 15 de março ao estabelecer que; "Os ocupantes do cargo de Delegado de Polícia Federal, autoridades policiais no âmbito da polícia judiciária da União, são responsáveis pela direção das atividades do órgão e exercem função de natureza jurídica e policial, essencial e exclusiva de Estado.” 
O conceito clássico de ato de autoridade é estabelecido como sendo toda a manifestação do Poder Público, exteriorizada e personificada através de pessoa física determinada, que investida do poder de decisão atua dentro da esfera de competência que lhe é atribuída através da norma legal, no âmbito da Polícia Judiciária o responsável legal é o Delegado de Polícia ${ }^{16}$, que ao determinar a realização de uma diligência, atua como autoridade e está decidindo com base na legislação em vigor, atendendo aos preceitos constitucionais e legais, subsumindo a norma a conduta, sendo tal ato decisório suscetível de eventual impugnação e responsabilização, que recairá única e exclusivamente sobre a Autoridade Policial determinante e detentora deste poder decisório e imparcial na condução do Processo de Investigação. ${ }^{17}$

Apesar da atividade policial, na visão geral, ser percebida na sua forma positiva, materializada nos atos de prender, efetuar buscas, apreender bens ilícitos, dentre outras, entretanto, cabe expressamente ao Delegado de Polícia decidir sobre algo mais importante, a liberdade individual do conduzido preso em flagrante, não efetuando a sua prisão quando esta não encontrar respaldo na norma penal, conforme se observa no artigo $7 .^{\circ}$, item 5 , do Decreto n. ${ }^{\circ} 678$, de 6 de Novembro 1992, que Promulga a Convenção Americana sobre Direitos Humanos - Pacto de São José da Costa Rica ,de 22 de Novembro de 1969 e estabelece:

\section{Artigo $7^{\circ}$ - Direito à liberdade pessoal:}

5. Toda pessoa presa, detida ou retida deve ser conduzida, sem demora, à presença de um juiz ou outra autoridade autorizada por lei a exercer funçôes judiciais e tem o direito de ser julgada em prazo razoável ou de ser posta em liberdade, sem prejuizo de que prossiga o processo. Sua liberdade pode ser condicionada a garantias que assegurem o seu comparecimento em juizo.

16 A exata distinção entre Autoridade e Agente da Autoridade, uma vez que o primeiro detém o poder de decisão, sendo competente para praticar atos decisórios, os quais quando maculados de ilegalidade ou abuso, são susceptíveis de impugnação por mandado de segurança, ao atingirem direito líquido e certo, ou por "habeas corpus" quando os atos recaírem sobre a liberdade individual. Desta forma o agente da autoridade não pratica qualquer ato decisório, limitando-se a cumprir ordens expedidas através dos atos executórios, não podendo, desta forma, ser responsabilizado ou qualificado como autoridade. (Meirelles 1989, pp. 10-11) Portanto o mero executor da ordem não pode ser apontado como autoridade nem no sentido legal e nem tampouco na acepção jurídica de tal conceito uma vez que é sobre quem decide, ou seja, quem pratica o ato de autoridade é que recai o ônus da decisão, no ato de autoridade encontramos o poder decisório de conteúdo deliberativo, e não apenas de conteúdo executivo (Werner, 2013, p.180).

17 A Exposição de motivos do Código de Processo Penal Decreto-Lei n. ${ }^{\circ} 3.689 / 1914$ de 3 de outubro manteve o inquérito policial como processo preliminar ou preparatório da ação penal, cuja análise será melhor desenvolvida a seguir. 
Identifica-se, aqui, a imprescindibilidade do Inquérito Policial, instrumento indispensável para a materialização efetiva dos Direitos e Garantias Individuais, assim, o poder decisório da Autoridade Policial deve ser resguardado e protegido, destacando-se: "a importância das atribuições do Delegado de Polícia que, na qualidade de Autoridade Policial, desempenha atividade típica de Estado, atuando no combate ao crime e aplicando a ciência jurídica nos casos concretos apresentados" (Justificativa - Projeto de Lei n. ${ }^{\circ} 7193 / 2010$ convertido na Lei.$^{\circ}$ 12.830/2012).

O Departamento de Polícia Federal é um "órgão estratégico para o sistema constitucional de segurança pública, que necessita aprimorar a sua estrutura interna de cargos e atribuições de maneira a exercer a sua missão com eficiência, efetividade e eficácia na prevenção e repressão dos crimes". (Justificativa apresentada na Medida Provisória n. ${ }^{\circ}$ 657/2014 convertida na Lei Ordinária n. ${ }^{\circ}$ 13.047/2014).

Observamos a tendência do legislador nacional em criar os mecanismos necessários a fim de impedir a nefasta ingerência do poder político e econômico sobre os atos de decisão das Autoridades Policiais no exercício das atividades de Polícia Judiciária ao fixar regras legais especificas e critérios de lotação, remoção e distribuição de inquéritos policiais de forma a possibilitar o exercício de suas funções de forma isenta, imparcial e republicana. ${ }^{18}$

Em uma democracia é inadmissível que determinados grupos, ao arrepio da lei, possam influir e definir o que será investigado, por quem, quando, de qual maneira, de forma a promover um ambiente propício à prevalência da imoralidade e da corrupção.

Merece destaque que, apesar da Polícia Judiciária encontrar-se constitucionalmente inserida no capítulo da Segurança Pública, mais adequado

18 A Lei n. ${ }^{\circ}$ 12.830/2013 de 20 de Junho, estabelece a condução da investigação criminal por Delegado de Polícia e estabelece no artigo 2o As funções de polícia judiciária e a apuração de infrações penais exercidas pelo delegado de polícia são de natureza jurídica, essenciais e exclusivas de Estado. $₫$ 1o Ao delegado de polícia, na qualidade de autoridade policial, cabe a condução da investigação criminal por meio de inquérito policial ou outro procedimento previsto em lei, que tem como objetivo a apuração das circunstâncias, da materialidade e da autoria das infrações penais. $\$ 20$ Durante a investigação criminal, cabe ao delegado de polícia a requisição de perícia, informações, documentos e dados que interessem à apuração dos fatos. $\$ 40 \mathrm{O}$ inquérito policial ou outro procedimento previsto em lei em curso somente poderá ser avocado ou redistribuído por superior hierárquico, mediante despacho fundamentado, por motivo de interesse público ou nas hipóteses de inobservância dos procedimentos previstos em regulamento da corporação que prejudique a eficácia da investigação. $\$ 50 \mathrm{~A}$ remoção do delegado de polícia dar-se-á somente por ato fundamentado. 
ao sistema político-constitucional deveria ser sua inserção no capítulo das Funções Essenciais à Justiça, por notadamente desempenhar atividade jurisdicional de juízo de instrução, conforme inclusive apresentado pelo Conselho da Ordem dos Advogados do Brasil em proposição de Emenda Constitucional ${ }^{19}$ redigida pelo jurista Fábio Konder Comparato (PEREIRA, 2013, pp. 29-31).

\section{APODERAMENTO: CLIENTELISMO, TOTALITARISMO}

O apoderamento pode ser expresso através de duas modalidades distintas, entretanto não excludentes, por um lado, na forma do clientelismo, dimensão da ingerência do público sobre o privado, reconhecido como um fenômeno histórico nacional identificável na submissão das instituições públicas a vontade das elites dominantes - público e o privado misturam-se em um único corpo-, e por outro lado, na forma do totalitarismo, onde o detentor do poder político, investido na figura do líder supremo, submete as instituições ao cumprimento da ideologia estatal e as pessoas são transformadas em instrumento do exercício do poder, sendo esta última modalidade, reconhecida também no populismo.

A viga mestra do Estado Democrático de Direito é identificável na máxima que todo o poder emanar do seu povo, que o exerce, por meio de representantes periodicamente eleitos ${ }^{20}$, sendo tal exercício o fundamento de legitimidade para a elaboração das leis alicerçadas na vontade geral, uma vez que o povo é o corpo de ação geral e coletiva, e, jamais, um indivíduo de ação particular, sendo este o pensamento incorporado ao moderno constitucionalismo. ${ }^{21}$

19 Consultado em 28 de Outubro de 2015 e disponível em: http://www.oab.org.br/editora/revista/ users/revista/1211292337174218181901.pdf

$20 \mathrm{O}$ artigo $1^{\circ}$ - Parágrafo Único da Constituição Federal observa uma clausula geral democrática da representação na elaboração das leis: "Todo o poder emana do povo, que o exerce por meio de representantes eleitos ou diretamente, nos termos desta Constituição".

21 Fundamentos teóricos da Ciência Política, no pensamento clássico de Montesquieu na obra O Espírito das Leis de 1748 ao estabelecer a importância do povo no processo de participação legislativa, e em especial com Jean-Jacques Rousseau na obra O Contrato Social de 1762, Capitulo V, bem ocmo no conceito da Vontade Geral desenvolvido por Jean-Jacques Rousseau recebe o reconhecimento histórico na Declaração dos Direitos do Homen e do Cidadão de 1789 no seu artigo $6^{\circ}$ ao embelecer: "A Lei é a expressão da vontade geral. Todos os cidadãos têm o direito de concorrer, pessoalmente ou através dos seus representantes, para a sua formação. Ela deve ser a mesma para todos, quer se destine a proteger quer a punir. Todos os cidadãos são iguais a seus olhos, são igualmente admissiveis a todas as 


\section{I. CLIENTELISMO}

O apoderamento é justamente o antagonismo da independência proposta no modelo democrático, sendo reconhecida nas formas deterioradas do exercício do poder e na errônea percepção da dicotomia público-privado, cria-se um ambiente propício onde os detentores do poder se apoderam do domínio público, transformando-o em extensão de seu próprio domínio privado, e, por conseguinte, o ideal republicano - res publica - transfigura-se no distanciamento abissal do plano teórico com o prático e, neste espaço, grassam as indiferenças, acomodações, omissões, a ignorância, complacência e o conformismo (ATALIBA, 1984, p. 8).

Os malefícios da ingerência na atividade pública encontram-se identificados e perpassam a historiografia da formação do Estado nacional brasileiro como resultantes da interdependência e da correlação entre três elementos fundamentais e indissociáveis de sua composição: a sociedade, as elites e a máquina burocrática, manifesta por meio da corrupção, expressão endêmica de tal promiscuidade.

Dois enfoques aparentemente distintos e, ao mesmo tempo, convergentes podem ser inicialmente identificados na manutenção do jogo de poder ao considerar o Estado brasileiro em seu caráter histórico: (1) Instrumento da classe economicamente preponderante, sendo a dominação política reflexo da dominação econômica, inexistindo uma elite política com interesse distinto da elite econômica (Prado Júnior: 2006:124-128); (2) Instrumento das relações de clientelismo, onde as elites rurais controlam as eleições indicando um afastamento destas com as elites políticas (MATTOS, 1987:171).

As complexas relações sociais estabelecidas no período do Brasil-Colônia e expressas no modelo de dominação da metrópole, criaram todos os matrizes das formas de controle das atividades jurisdicionais e alicerçaram, posteriormente, o modelo coronelista da ingerência do privado sobre o público, do apoderamento das instituições policiais, judicial e eleitorais como instrumento para a perpetuação no poder dos grandes proprietários de terra, os coronéis e toda a sua entourage, reforçando os modelos do governismo dos chefes locais em alianças para "fazer a justiça" aos amigos e "aplicar a lei" aos adversários, legitimado por um sistema eleitoral fraudulento (LEAL, 2012: 203-204)

dignidades, lugares e empregos públicos, segundo a sua capacidade, e sem outra distinção que não seja a das suas virtudes e dos seus talentos." 
O modelo Judicial e de Polícia Judiciária adotado no Brasil oitocentista esteve previsto na Lei de 15 de Outubro de $1827^{22}$ e atribuía a função de investigação aos magistrados, especificamente aos Juízes de Paz, cuja atribuição era de conciliar as partes, que pretendem demandar, julgar pequenas demandas e fazer o auto de corpo de delito, percebendo os mesmos emolumentos que o Juiz de Direito, trata-se do legado do sistema de administração da justiça português onde as atividades de polícia judiciária integravam-se a magistratura (FLORY 1986, pp 74-77).

A reforma do Código de Processo Criminal de 1841 regulava a atividade dos juízes modificou as atuações da Polícia Judiciária, sendo a expressão do instrumento conservador da época ao criar mecanismos de total controle sobre a estrutura administrativa e judiciária do Império assim:

Todos os juizes, desembargador, de juiz de direito a juiz municipal, deviam ser nomeados pelo ministro da Justiça. Sobretudo os juizes de direito tiveram seus poderes reforçados. Somente os juizes de paz locais continuaram independentes do poder central. Mas cuidou-se disso também: a nova lei criou chefes de policia em todas as capitais das provincias - nomeados pelo ministro da Justiça. No municipio e na freguesia, os chefes de policia eram representados por delegados e subdelegados, civis nomeados pelos presidentes de provincia por recomendação dos próprios chefes de polícia. A maioria das atribuiçôes de justiça e de polícia, até então exclusivas dos juizes de paz, foram transferidas para os delegados e subdelegados, reduzindo à impotência os juizes eleitos. (CARVALHO, 2010, p. 733)

A finalidade era subordinar de maneira estreita a ação judiciária e policial ao Governo-Geral, possibilitando, assim, um melhor controle e fiscalização das atividades econômicas, especificamente no combate a atividade dos traficantes e atravessadores, embora pudesse permitir o comércio negreiro, distinguindo e discriminando aqueles que poderiam exercer um monopólio e os demais que deveriam ser excluídos das atividades econômicas. (MATTOS, 1987, p. 165)

Criou-se um corpo de Polícia Judiciária próxima o bastante do Poder Judiciário para desempenhar as atribuiçõoes que este não queriam desempenhar, como prender criminosos e investigar os crimes, mas distante o bastante para sobre esta instituição não incidirem as garantias do próprio Poder Judiciário, como isenção e autonomia, possibilitando assim tornar mais fácil

22 A Lei de 15 de Outubro de 1827 em seu Art. $5^{\circ}$ estabelecia as funções do Juiz de Paz, conforme Coleção de Leis do Império do Brasil - 1827, Página 67 Vol. 1 pt. I 
o seu controle, neste sentido, a Polícia Judiciária tinha "a meta de suprimir e subjugar, manter um nível aceitável de ordem e tranquilidade que possibilitasse o funcionamento da cidade no interesse da classe que elaborou as regras e criou a polícia para fazê-las cumprir" (HOLLOWAY, 1997, p. 50)

Os "donos do poder" criaram o Estado patrimonial, que nasce e se desenvolve com o propósito de manter impenetrável e impermeável o círculo de comando, o núcleo dirigente que atua em nome próprio, servindo-se e apoderando-se dos instrumentos políticos e do aparelhamento estatal, assim:

Este curso histórico leva à admissão de um sistema de forças politicas, que sociólogos e historiadores relutam em reconhecer, atemorizados pelo paradoxo, em nome de premissas teóricas de vária indole. Sobre a sociedade, acima das classes, o aparelhamento politico uma camada social, comunitária embora nem sempre articulada, amorfa muitas vezes - impera, rege e governa, em nome próprio, num círculo impermeável de comando. Esta camada muda e se renova, mas não representa a nação, senão que, forçada pela lei do tempo, substitui moços por velhos, aptos por inaptos, num processo que cunha e nobilita os recém-vindos, imprimindo-lhes os seus valores." (FAORO, 2001: 871)

A dinâmica do apoderamento institucional não poupa a máquina pública e seu corpo político, os círculos do poder, quando submetido aos interesses privados e particulares específicos de oligarquias tendem a impor o relacionamento patronal e a vontade particular dos detentores do poder sobre o interesse público, assim:

No Brasil, pode dizer-se que só excepcionalmente tivemos um sistema administrativo e um corpo de funcionários puramente dedicados a interesses objetivos e fundados nesses interesses. Ao contrário, épossivel acompanhar, ao longo de nossa história, o predominio constante das vontades particulares que encontram seu ambiente próprio em círculos fechados e pouco acessiveis a uma ordenação impessoal. Dentre esses circulos, foi sem dúvida o da familia aquele que se exprimiu com mais força e desenvoltura em nossa sociedade. Eum dos efeitos decisivos da supremacia incontestável, absorvente, do núcleo familiar - a esfera, por excelência dos chamados "contatos primários", dos laços de sangue e de coração - em que as relações que se criam na vida doméstica sempre forneceram o modelo obrigatório de qualquer composição social entre nos. Isso ocorre mesmo onde as instituições democráticas, fundadas em princípios neutros e abstratos, pretendem assentar a sociedade em normas antiparticularistas." 


\section{$[\ldots]$}

"Para o funcionário 'patrimonial', a própria gestão politica apresenta-se como assunto de seu interesse particular; as funçôes, os empregos e os beneficios que deles aufere relacionam-se a direitos pessoais do funcionário e não a interesses objetivos, como sucede no verdadeiro Estado burocrático, em que prevalecem a especialização das funções e o esforço para se assegurarem garantias juridicas aos cidadãos." (BUARQUE DE HOLANDA, 1995, pp. 146-147)

A análise do Brasil a partir das dicotomias representam as variações em torno do tema clássico sistema de análise de "dois Brasis" ${ }^{23}$, notadamente na identificação dos contrapontos de desenvolvimento versus subdesenvolvimento, Brasil urbano versus Brasil rural, industrialização versus oligarquia rural, poder publico versus ordem privada, centralização versus poder, em termos das tensões constantes entre dois polos, que se alternam em ciclos intermináveis ou entre dois polos que permanecem em contradições mutuas, tais dicotomias mostraram-se uteis, entretanto o sistema institucional evoluiu para uma forma que transcende a noção dos “dois Brasis", trata-se de uma crítica ao dualismo neomarxista focada no modo de produção com enfoque meramente econômico, entretanto as relações de classes devem ser observadas, não apenas sob a esfera econômica, mas de forma a identificar como os sistemas políticos agregam ou desagregam as relações de classes. (NUNES, 2003, pp. 16-17).

No processo de adoção do capitalismo moderno, o Brasil teve de criar muitas instituições novas, em período de tempo relativamente curto e de forma contrária a proposição de Weber e Polany, da lógica impessoal das modernas relações entre a sociedade e as instituições políticas, e apresentam-se em quatro padrões institucionalizados de relação ou gramáticas que estruturam os laços de relação entre a sociedade e as instituições políticas: (1) clientelismo, (2) corporativismo, (3) insulamento burocrático e (4) universalismo de procedimentos, destacando o clientelismo cujo vínculo básico é a interdependência sócio institucional, onde a ingerência do privado na po-

23 Autores como Nestor Duarte, Oliveira Viana e Victor Nunes Leal enfatizaram a importância do poder privado como uma barreira à construção de uma ordem pública, por seu turno Oliveira Viana, Francisco Campos, Raimundo Faoro e Simon Schwartzman investigaram o uso do poder publico na criação de uma ordem estatal e finalmente estudiosos como Maria Isaura Pereira de Queiros a Golbery do Couto e Silva, enfatizaram a importância de sucessivos momentos de centralização e descentralização, de sístole e diástole, na formação da sociedade e do Estado brasileiro, recordando a expressão Belíndia de Edmar Bacha, sendo uma ideia que exerce permanente fascínio, em suas variadas formas, sobre a vida intelectual brasileira. (NUNES, 2003, p.16) 
lítica e do político no institucional cria um sistema de "controle do fluxo de recursos materiais e de intermediação de interesses, no qual não há número fixo ou organizado de unidades constitutivas", nascem as relações interpessoais que repousam na troca generalizada sem qualquer respaldo jurídico e ao arrepio da lei. (NUNES, 2003, pp. 40-41)

Essa herança histórica nacional confere força à corrupção permeando-a na trama do tecido social ao estabelecer complexas relações de poder dentro das instituições de Estado nacional e a sociedade patriarcal expressa na velha máxima popular "você sabe com quem está falando?", o dogma fundamental de legitimidade dos governantes ao fazerem tudo o que lhe apraz, projetando-se sobre seus mandatários e impondo a estes o comportamento servil e subserviente da mais velhaca política, com a criação de verdadeiros feudos clientelistas e corruptos.

A correlação do estado institucional é observável na conformação das políticas públicas e dos partidos políticos brasileiros, sendo o clientelismo uma das características mais marcantes da República Velha, e presente na política dos governadores em um jogo da alternância no poder pré-estabelecido, uma marca do Brasil arcaico, ainda hoje observável, uma vez que:

O clientelismo político, no entanto, permanece bastante vivo, $O$ clientelismo se manteve forte no decorrer de periodos democráticos, não definhou durante o periodo de autoritarismo, não foi extinto pela industrialização e não demonstrou sinais de fraqueza no decorrer da abertura politica. O universalismo de procedimentos e $o$ insulamento burocrático são muitas vezes percebidos como formas apropriadas de contrabalançar o clientelismo. O universalismo de procedimentos, baseado nas normas de impersonalismo, direitos iguais perante a lei, e checks and balances, refrear e desafiar os favores pessoais. De outro lado, o insulamento burocrático e percebido como uma estratégia para contornar o clientelismo através da criação de ilhas de racionalidade e de especialização técnica." (NUNES, 2003, pp.33-34)

O insulamento burocrático "na linguagem da teoria organizacional contemporânea o insulamento burocrático é o processo de proteção do núcleo técnico do Estado contra a interferência oriunda do público ou de outras organizações intermediárias." (NUNES, 2003, pp. 33-34)

Sua origem remonta à criação e transformação do Tribunal de Contas da União, deste a Constituição de 1891, e na necessidade, já naquela épo- 
ca, de dotá-lo de autonomia e independência, tendo a Constituição de 1988 conferido o papel de auxiliar ao Congresso Nacional, assim observamos:

Criado por iniciativa de Ruy Barbosa, em 1890, o Tribunal de Contas é instituição estatal independente, pois seus integrantes têm as mesmas garantias atribuidas ao Poder Judiciário (CF, art. 73, $\mathbb{I}$ $3^{\circ}$ ). Dai ser impossivel considerá-lo subordinado ou inserido na estrutura do Legislativo. Se a sua função é atuar em auxilio ao Legislativo, sua natureza, em razão das próprias normas constitucionais, é a de órgão independente, desvinculado da estrutura de qualquer dos três poderes" (MEDAUAR, 2003, p. 421).

Outros exemplos de insulamento institucional podem ser identificados na autonomia prevista na Lei n. ${ }^{\circ} 6.385 / 1976$, que cria a Comissão de Valores Mobiliários $(\mathrm{CVM})^{24}$, com a missão de fiscalizar e organizar e distribuição de títulos e valores mobiliários e o Sistema Financeiro Nacional.

O insulamento burocrático tornou-se medida central na reforma administrativa brasileira iniciada durante o regime militar, mantendo-se com a abertura política e ganhando destaque durante o processo das privatizações através da criação dos agentes normativos e das agências reguladoras das atividades econômicas de Estado. ${ }^{25}$

Instituições como a Agência Nacional de Petróleo (ANP) - Lei no 9.478/97 - e Agência Nacional de Vigilância Sanitária (ANVISA) - Lei no 9.782/99 -, dentre outras, ${ }^{26}$ delinearam-se na forma de autarquia dotadas de

24 Neste sentido o Art. 5o É instituida a Comissão de Valores Mobiliários, entidade autárquica em regime especial, vinculada ao Ministério da Fazenda, com personalidade jurídica e patrimônio próprios, dotada de autoridade administrativa independente, ausência de subordinação hierárquica, mandato fixo e estabilidade de seus dirigentes, e autonomia financeira e orçamentária. (Redação dada pela Lei ${ }^{\circ}$ 10.411, de 26.2.2002).

25 Conforme previsto na Constituição Federal no Art. 174. Como agente normativo e regulador da atividade econômica, o Estado exercerá, na forma da lei, as funções de fiscalização, incentivo e planejamento, sendo este determinante para o setor público e indicativo para o setor privado. $\S 1^{\circ}$ A lei estabelecerá as diretrizes e bases do planejamento do desenvolvimento nacional equilibrado, o qual incorporará e compatibilizará os planos nacionais e regionais de desenvolvimento. $\$ 2^{\circ} \mathrm{A}$ lei apoiará e estimulará o cooperativismo e outras formas de associativismo. $₫ 3^{\circ} \mathrm{O}$ Estado favorecerá a organização da atividade garimpeira em cooperativas, levando em conta a proteção do meio ambiente e a promoção econômico-social dos garimpeiros. $\$ 4^{\circ}$ As cooperativas a que se refere o parágrafo anterior terão prioridade na autorização ou concessão para pesquisa e lavra dos recursos e jazidas de minerais garimpáveis, nas áreas onde estejam atuando, e naquelas fixadas de acordo com o art. 21, $\mathrm{XXV}$, na forma da lei.

26 Agencias Reguladoras como a Agência Nacional de Energia Elétrica (ANEL) Lei 9.427/96; Agência Nacional de Telecomunicações (ANATEL) Lei 9.472/97; Agência Nacional de Saúde Suplementar 
autonomia administrativa, técnica e financeira, objetivando sua proteção institucional em razão das atividades de fiscalização que desempenham, neste contexto, destaca-se a autonomia financeira e a possibilidade do autofinanciamento, uma vez que as receitas próprias são arrecadadas na forma de taxas de regulamentação e fiscalização.

A autonomia para órgãos, como o Tribunal de Contas da União, Agências Reguladoras e Comissão de Valores Mobiliários, justifica-se na necessidade de proteção das atividades econômicas desenvolvidas pelo Estado, sua capacidade interventiva no mercado através de medidas econômicas de fiscalização da aplicação das diretrizes e bases do planejamento buscando o desenvolvimento nacional equilibrado e um Sistema Financeiro Nacional protegido. ${ }^{27}$

É importante destacar o anacronismo institucional criado, uma vez que os órgãos de fiscalização se encontram protegidos e insulados com autonomia administrativa, funcional e financeira, por serem instituições de Estado voltadas à fiscalização de bens jurídicos, como se observa nas instituições que promovem atividades de fiscalização administrativa, e muita das vezes, produz procedimentos que acabam por instruir Inquéritos Policiais destinados a investigar no âmbito penal os desvios praticados.

(ANS) Lei 9.961/00; Agência Nacional de Águas (ANA) Lei 9.984/00; Agência Nacional de Transporte Aquaviário (ANTAQ) Lei 10.233/01; Agência Nacional de Transporte Terrestre (ANTT) Lei 10.233/01; Agência de Desenvolvimento do Nordeste Lei 11.182/05; Agência de Desenvolvimento da Amazônia - Medida Provisória n. ${ }^{\circ}$ 2.156-5/01; Agência Nacional do Cinema (ANCINE) - Medida Provisória n. ${ }^{\circ}$ 2.157-5/01 e Agência Nacional de Aviação Civil (ANAC) Medida Provisória n. ${ }^{\circ}$ 2.228-1/01 com autonomia na forma de suas leis instituidoras.

27 Sistema Financeiro Nacional que compreende o conjunto de instituições financeiras volta $\neg$ das para a gestão da política monetária do governo, sob a orientação do Conselho Monetário Nacional (CMN), abrangendo também Banco Central do Brasil, Banco do Brasil, Banco Nacional de Desenvolvimento Econômico e Social e bancos regionais de desenvolvimento, Banco Nacional da Habitação, sociedades de crédito imobiliário, associações de poupança e empréstimo, cooperativas habitacionais, Caixa Econômica Federal e dos Estados, bolsa de valores, fundos de investimentos, sociedades financeiras, de crédito e financiamento, distribuidoras de valores e corretoras (Carmo Lopes e Rossetti 1987 Economia Monetária - Ed Atlas p. 316) O conjunto articulado de instituições financeiras, ou entes a ela equiparados, públicos ou privados, que correspondem ao modelo expressamente definido em lei e estruturados com o escopo de "promover o desenvolvimento equilibrado do Pais e a servir aos interesses da coletividade", instituições em atuação na captação, gestão e aplicação de recursos financeiros e valores mobiliários de terceiros - quer entes públicos ou privados - sob a fiscalização do Estado, bem como as relações jurídicas existentes entre tais instituições, seus usuários, seus funcionários e o poder público (Rodolfo Tigre Maia - Dos Crimes Contra o Sistema Financeiro Nacional - Anotações à Lei Federal n. 7.492/86, São Paulo: Malheiros, p.. 28). 
Entretanto, a Polícia Federal, cuja missão institucional é investigar, apurar crimes contra o patrimônio da União e, especificamente, atuar na proteção do Sistema Financeiro Nacional e das verbas públicas, não se encontra protegida com igual garantia institucional de autonomia e desempenha todos os atos de Polícia Judiciária, voltados para a investigação criminal e materializados através do Inquérito Policial.

Terminados os trabalhos de Polícia Judiciária, as demais instituições de acusação e julgamento quais sejam Ministério Público e Poder Judiciário voltam a deter as prerrogativas ainda mais abrangentes de autonomia do que as autarquias e agências responsáveis por efetuar a fiscalização administrativa inicial.

Assim, a autonomia das Polícias Judiciárias, e especificamente no caso da Polícia Federal, é primordial, sendo condição determinante de sua efetividade e legalidade, uma vez que sua atuação se encontra orientada por normas legais embasadas na ética profissional e no respeito aos direitos e garantias, considerando todos de forma equânime e justa, sem distinções ou apriorismos, sendo esta a marcas dos sistemas políticos democráticos que deve proteger suas instituições das ingerências externas.

\subsection{TOTALITARISMO, POPULISMO E NEOPOPULISMO}

A segunda forma de apoderamento é identificada em estados totalitários, onde o modelo político desenhado pelos detentores do poder submetem as instituições à vontade do líder ou de uma determinada ideologia, foi assim, no nacional socialismo e nos regimes socialistas e, sempre o será nas ditaduras.

Identificar e distinguir o totalitário do legitimo é uma tarefa aparentemente fácil, entretanto, apresenta algumas armadilhas conceituais, para tanto as estruturas propostas por Max Weber para delinear as três formas de dominação (legal, tradicional e carismática) atendem a esta tarefa (WEBER, 2008:, pp. 139-188).

O modelo weberiano de dominação legal auxilia a compreensão do Estado Liberal de contorno democrático, onde prevalece o império da lei e apresenta como política criminal um conjunto legislativo que define as infrações e justifica a medida da resposta estatal, ou seja, na impossibilidade de 
definir com precisão o desvio de conduta ${ }^{28}$, o Estado não está autorizado a intervir neste campo, que continua reservado à sociedade civil (DELMAS-MARTY, 2004, p. 97).

No contexto da dominação legal, a autonomia das instituições faz-se necessária para tornar legitimo o império da lei dentro de determinado grupo social, sendo o domínio a probabilidade de se encontrar obediência para as ordens específicas dentro de um determinado grupo social, entretanto observamos que:

nem toda posição de poder econômica manifesta-se como logo perceberemos - como "dominação" no sentido aqui adotado da palavra. E nem toda "dominação" se serve, para sua fundação e conservação, de meios coativos econômicos. Mas, na grande maioria das formas de dominação, e precisamente nas mais importantes, este é, de alguma maneira, o caso, e muitas vezes numa proporção tão grande que, por sua vez, o modo como os meios econômicos são empregados para conservar a dominação influência, decisivamente, o caráter da estrutura de dominação." (WEBER, 2008, p.188)

O apoderamento do Estado Liberal já foi descrito no modelo clientelista, resta agora, no contexto weberiano, discutir as formas de dominação tradicional, carismática e seus matizes de apoderação, onde o primeiro se deturpa, transforma-se no totalitarismo e, o segundo, no populismo.

A intervenção do político nas atividades de estado correlacionadas com as liberdades públicas, nos regimes de dominação tradicional, correspondente aos estados de autoridade (monárquicos), ${ }^{29}$ nos quais os governados estão sujeitos a autoridade pessoal fundada nas crenças, regras e poderes antigos, tradicionais e imutáveis (WEBER, 2008, pp. 148-158), apresentam como resposta estatal uma ação tanto voltada contra o delinquente, quanto ao desviante, como condição para que seja respeitada a tradição e os costumes (DELMAS-MARTY, 2004, p. 97), da mesma forma

28 "Na nova teoria do desvio, o desviante é, acima de tudo, um ator consciente, racional, livre dos determinantes dos eventos passados e distúrbios físicos ou psíquicos, e existindo em uma homogênea e normativamente consistente subcultura; os conceitos de subsocialização e desorganização social como causas do desvio são substituidos por uma ênfase na socialização diferencial dos individuos dependente da sua proximidade de uma organização social normativa particular dentro da pluralidade de organizações que formam a sociedade total" (TAYLOR et al 1980: 312).

29 É importante destacar que o modelo de dominação tradicional é materializável e observável nas monarquias constitucionais onde o povo é o detentor e guardião da vontade geral expressa nas leis e nos costumes e o soberano detém o poder de representante legitimo desta vontade, o sistema pode se deturpar e apresentar-se na forma de monarquia despótica ou tirânica. 
que, o modelo de dominação carismática, correspondente aos Estados ditatoriais e tiranos, encontra-se centrado em qualidades pessoais do líder chamado a cumprir uma missão, uma pessoa a qual se atribui poderes ou qualidades sobrenaturais e extraordinárias fundadas no carisma, o Estado funda sua legitimidade na confiança que o líder inspira em seus subordinados (WEBER; 1999, pp. 158-167) a resposta estatal se estabelece em regras desprovidas de critérios de garantia individual, o limite do Estado será fixado pelo líder em um sistema onde a resposta estatal recai indistintamente sobre a infração e o desvio (DELMAS-MARTY, 2004. p. 97)

No modelo totalitário puro as instituições que detêm o poder de decisão sobre atos de constrição de direitos e da própria liberdade individual, especificamente o Poder Judiciário e a Polícia Judiciária, em modelos tradicionais ou carismáticos tendem a sofrer forte pressão da ingerência política ao decidir sobre matéria afeta a liberdade individual uma vez que qualquer forma de ameaça a vontade do detentor do poder corresponde a uma medida de ação destinada à proteção dos seus interesses e esta medida é realizável por instituições de persecução penal opacas e desprovidas de controle, o povo não sabe o que elas representam a não ser através da propaganda oficial.

A degeneração da dominação carismática é nítida e observável ,tanto no plano funcional, com a retirada da autonomia institucional criando um ambiente no qual o menor descumprimento da vontade do líder recebe enérgica e rigorosa punição com a remoção, demissão e até substituição dos chefes que permitiram tal desatino ou não o coibiram prontamente e, no plano institucional, retira-se as atribuições e recursos, esvaziando-a.

O populismo pode ser compreendido como a fórmula política autoritária onde o líder por meio de seu carisma incorpora em sua estratégia de ascensão ao poder os grupos excluídos, obtendo legitimidade destes através da manipulação demagógica (GERMANI, 1979, p. 322 e IANNI, 1973, pp. 83-86), como observável no Peronismo Argentino. ${ }^{30}$

$\mathrm{Na}$ America Latina, o populismo clássico é observado no período compreendido entre os anos 40 e 70 e, o neopopulismo, pode ser observa-

30 Um exemplo do populismo Latino Americano bastante estudado é o do Peronismo Argentino, onde Juan Domingos Perón por meio de constantes comícios em sindicatos e fabricas e discursos através do rádio o colocaram como a única alternativa e solução para os trabalhadores argentinos (GERMANI, 2010, p. 618). 
do a partir dos anos 90. O primeiro sofre grande influência da Guerra Fria e do confronto capitalismo versus socialismo, leste contra oeste, o segundo momento, supera a bipolaridade com o colapso do bloco comunista, contexto onde o neopopulismo modifica parcialmente sua retórica inserindo características culturais nacionalistas no discurso socialista para firmar-se como alternativa legítima e única via de construção de uma identidade de unidade nacional, a ideologia segue passo a maior carga demagógica como observável nos governos de Hugo Chaves, Evo Morales e Rafael Correa e outros do nosso continente.

A dominação, tanto totalitária, quanto populista, para ser exercida deve estar instrumentalizada em instituições obedientes à vontade do líder, e desprovidas de qualquer autonomia, a função de proteção das liberdades e garantias individuais sede passo ao cumprimento cego e autômato da vontade do líder que apodera ou substitui organismos estatais por entidades obedientes, assim:

O dever da polícia totalitária não é descobrir crimes, mas estar disponivel quando o governo decide aprisionar ou liquidar certa categoria da população. Sua principal distinção política é que somente ela confidencia com a mais alta autoridade e sabe que linha politica será adotada" (ARENDT, 2000, p. 476)

\section{USURPAÇÃO: A ARTE dE TORNAR OPACO O QUE É CLARO}

A usurpação é a prática ilegal de realizar atribuições exclusivas de outros órgãos como o objetivo de ampliar a zona de influência e o poder institucional ou impossibilitar a correta realização das atividades legalmente desenhada com a invasão de atribuições e competências de determinado órgão sobre outro, em patente ruptura com as garantias republicanas e de defesa da democracia e da segurança jurídica.

O exemplo anteriormente apontado, do Parecer n. ${ }^{\circ}$ 4.330/2015-AsJConst/SAJ/PGR da Procuradoria-Geral da República, refere-se ao Inquérito Policial como "ineficiente, burocrático e bacharelesco, em mimetismo desnecessário, redundante, do processo judicial, em tentativa de torná-lo instrumento de natureza eminentemente administrativa, não jurídica”. Apresenta a retórica oculta de desconstruir a atividade constitucio- 
nalmente prevista para a Polícia Judiciária e ocupar seu espaço por meio de Procedimentos de Investigação Criminal (PIC), de forma ilegítima e ilegal.

Trata-se de uma invasão de atribuição que extrapola o balizamento legal conferido ao Ministério Público e afronta as demais Instituições republicanas, pondo em risco a segurança jurídica e os instrumentos de garantia processual, em patente desequilíbrio das partes no processo, o que, por si só, afronta ao Princípio do Contraditório e da Ampla Defesa.

A Constituição Federal estabelece as atribuições específicas ao Ministério Público conforme se observa:

Art. 129. São funções institucionais do Ministério Público:

I-promover, privativamente, a ação penal pública, na forma da lei; (...)

IlI - promover o inquérito civil e a ação civil pública, para a proteção do patrimônio público e social, do meio ambiente e de outros interesses difusos e coletivos;

(...)

VIl-exercer o controle externo da atividade policial, na forma da lei complementar mencionada no artigo anterior;

VIII - requisitar diligências investigatórias e a instauração de inquérito policial, indicados os fundamentos jurídicos de suas manifestações processuais." (g.n.)

A atribuição do exercício dos atos de Polícia Judiciária ao Departamento de Polícia Federal é clara e explícita no texto da Constituição Federal assim observo:

Art. 144. A segurança pública, dever do Estado, direito e responsabilidade de todos, é exercida para a preservação da ordem pública e da incolumidade das pessoas e do patrimônio, através dos seguintes órgãos:

I- Policia Federal;

II - Polícia Rodoviária Federal;

IlI - Polícia Ferroviária Federal;

IV - Policiais Civis;

V-Policias Militares e Corpo de Bombeiros Militares.

$\$ 1^{\circ}$ A Polícia Federal, instituida por lei como órgão permanente, 
organizado e mantido pela União e estruturada em carreira, destina-se a:

[...]

$I V$ - exercer, com exclusividade, as funções de policia judiciária da União.

[...]

$54^{\circ}$. As Polícias Civis, dirigidas por delegados de polícia de carreira, incumbem, ressalvada a competência da União, as funções de policia judiciária e a apuração de infrações penais, exceto as militares." (g.n.)

A investigação feita pelo Ministério Público colide com expressa disposição constitucional, uma vez que, o exercício exclusivo das funções de Polícia Judiciária da União recai sobre a Polícia Federal, neste sentido, destaca-se o teor da manifestação da Advocacia Geral da União, na Ação Direta de Inconstitucionalidade n. ${ }^{\circ} 4220$, assim:

O Poder Constituinte, ao tempo que concedeu atribuição institucional ao Ministério Público na promoção de procedimentos investigatórios e inquisitórios na proteção de direitos difusos e coletivos -todos de natureza civil e outorgou às Policias Federal e Civil a competência para o exercício das atividades de polícia judiciária".

[...]

É conhecida nas letras juridicas a tese-geralmente defendida por membros do Ministério Público - segundo a qual a função investigatória criminal seria um "poder implícito" outorgado pela Lei Magna ao órgão ministerial, uma vez que a ele foi conferida a competência de requisitar diligências investigatórias e a instauração de inquérito policial, bem como a atribuição de exercer o controle externo da atividade policial, abrindo-lhe espaço, implicitamente, para a realização direta de tais atividades.

No entanto, tal interpretação revela-se em descompasso com a literalidade dos dispositivos constitucionais referidos.

Em verdade, sabe-se que a interpretação literal não é suficiente para a total apreensão do fenômeno normativo, sendo certo que Savigny já alertava sobre a necessidade de que tal método fosse conjugado com outros meios interpretativos (interpretação sistemática, histórica, teleológica, dentre outras). Sabe-se, ademais, que a moderna hermenêutica assevera que a norma não é pressuposto do labor interpretativo, mas o seu resultado. Consoante Friedrich Müller, autor da teoria estruturante do Direito, o texto da Constituição ou da lei é "apenas a ponta do iceberg normativo. 
A constituição ao atribuir funções institucionais delimita seu exercício à forma exclusiva e privativa, aquela indelegável e está delegável, sendo exclusiva a atividade que somente pode ser realizada ou praticada pelo detentor da autoridade ou competência para fazê-lo, em detrimento das demais instituições (ALMEIDA, 2013, pp. 62-64)

O contexto jurídico apresentado de exclusividade não permite interpretações, nem tampouco, a aplicação da Teoria dos Poderes Implícitos, utilizada para legitimar a atuação do Ministério Público Federal no exercício de atividade de como Polícia Judiciária da União. Neste sentido destaca-se o pensamento do Ministro Marco Aurélio do Supremo Tribunal Federal ${ }^{31}$ :

A evocação do axioma jurídico "quem pode o mais pode o menos" estaria correta se estivéssemos diante de interpretação de normas de direito privado. Nessa seara, realmente, quem possui autorização para fazer o mais pode fazer o menos, pois, para os particulares, vale o princípio da legalidade ampla, ou seja, tudo que não estiver proibido está permitido. No direito público, aplica-se o princípio da legalidade estrita. Logo, os órgãos só podem proceder em conformidade com o que está expressamente autorizado. A ausência de previsão conduz à vedação. Descabe a aplicação da teoria dos poderes implícitos, pois a medida pressupõe vácuo normativo. Somente se a Carta não houvesse disciplinado acerca da investigação criminal, se mostraria possivel a observância dessa teoria com a finalidade de suprir a omissão do constituinte. ${ }^{32}$

A citada decisão afasta a "Teoria dos Poderes Implícitos" como instrumento de interpretação das normas de Direito Público, seara onde a administração cabe apenas fazer o que a lei determina, Melhor opção seria a aplicação da "Teoria dos Poderes Expressos", baseada na aceitação da norma legal partindo da leitura direta do texto constitucional, se não fosse assim, estaríamos diante da constante invasão de atribuição entre órgãos públicos, desvirtuando a própria gênese da república como o governo da lei voltada ao bem comum, onde cada instituição detém um papel especifico a ser desempe-

31 Voto-Vista do Ministro Marco Aurélio dando provimento ao recurso ao anular, desde a origem, o Processo-Crime no 1.0000.06.444038-1/000, que tramita perante o Tribunal de Justiça do Estado de Minas Gerais, proclamando a ilegitimidade absoluta do Ministério Público para, por meios próprios, realizar investigações criminais.

32 Neste sentido o Supremo Tribunal Federal já havia se posicionado por diversas vezes destacando: EMENTA: O MP deve requisitar investigações a policia, não cabe ao membro do Ministério Público realizar, diretamente, investigações tendentes à apuração de infrações penais, mas requisitá-las à autoridade policial, competente para tal. (CF, art 144, $\$ \$ 1^{\circ}$ e $4^{\circ}$ ) (STF, Inf, STF 142, RE 205.473 AL Rel. Min. Carlos Veloso). 
nhado e passaríamos ao anacronismo da usurpação, do arbítrio, rompendo-se com a Segurança Jurídica ${ }^{33}$ compreendida nas suas duas dimensões:

(1) estabilidade ou eficácia ex post da segurança jurídica: uma vez adotadas, na forma e procedimento legalmente exigidos, as decisöes estaduais não devem poder ser arbitrariamente modificadas, sendo apenas razoável alteração das mesmas quando ocorram pressupostos materiais particularmente relevantes. (2) previsibilidade ou eficácia ex ante do principio da segurança jurídica que, fundamentalmente, se reconduz à exigência de certeza e calculabilidade, por parte dos cidadãos, em relação aos efeitos jurídicos dos atos normativos. (CANOTILHO, 1995, p. 380)

As investigações promovidas por outras instituições, destacando as Comissões Parlamentares de Inquérito, conforme previsão do artigo $58, \S 3^{\circ}$, da Constituição Federal ou, até nas investigações promovidas no âmbito do Conselho de Controle de Atividades Financeiras (COAF), nos casos afetos a movimentações financeiras irregulares e remessas ao exterior ou pelo Conselho Administrativo de Defesa Econômica (CADE) nas medidas administrativas de verificação de formação de cartéis, não são investigações criminais, mas sim procedimentos administrativos destinados a coleta de informações destinadas a apurar irregularidades administrativas e práticas abusivas.

A legislação determina que após o encerramento dos procedimentos administrativos ou mesmo durante sua instrução, se observado fato ilícito, este seja comunicado prontamente para a Polícia Judiciária da União, quando a matéria for de competência da Justiça Federal, para a pronta instauração de Inquérito Policial, uma vez que quando um ilícito penal é praticado, quem tem o dever de agir é a Polícia Judiciária (DI PIETRO, 2001: 111)

Assim, as informações coletadas em procedimento administrativo devem ser encaminhadas para instauração de Inquérito Policial, sob pena de nulidade das provas, uma vez caber à Polícia Judiciária a função de apurar infrações penais e descobrir a autora delitiva, exercidas com exclusividade pelo Delegado de Polícia, sendo atividade de natureza jurídica, essenciais e exclusivas de Estado nos termos do artigo $2^{\circ}$ da Lei n. ${ }^{\circ}$ 12.830/2013.

33 A segurança jurídica encontra-se umbilicalmente ligada ao direito adqui $\neg$ rido, ato jurídico perfeito e coisa julgada, assim "os princípios da protecção da confiança e da segurança jurídica podem formularse assim: o cidadão deve poder confiar em que aos seus actos ou às decisões públicas incidentes sobre os seus direitos, posiçôes jurídicas e relações, praticados ou toma $\neg$ das de acordo com as normas jurídicas vigentes, se ligam os efeitos jurídicos dura $\neg$ douros, previstos ou calculados com base nessas mesmas normas. Estes princípios apontam basicamente para: (1) a proibição de leis retroactivas; (2) a inalterabi $\neg$ lidade do caso julgado; (3) a tendencial irrevogabilidade de actos administrativos constitutivos de direitos." (CANOTILHO, 1995, p. 373). 
Destaca-se que os relatórios produzidos por órgão administrativos e pelas Comissões Parlamentares, não podem ser considerados como prova suficiente para subsidiar a denúncia nos termos do artigo 41 do Código de Processo Penal, com a capacidade de ensejar uma ação penal livre de percalços, demonstrando, assim, a premente necessidade da instauração de idônea investigação criminal, a fim de se identificar todos os envolvidos o modo pelo qual foram realizadas as condutas delitivas individualizando as mesmas. ${ }^{34}$

Nesse sentido, é importante também observar o conteúdo do artigo $4^{\circ}$ do Código de Processo Penal ao definir as atribuições da Polícia Judiciária de apurar as infrações penais objetivando a coleta de provas destinadas a comprovar a materialidade e identificar a autoria delitiva.

A perigosa desconstrução Institucional não poupa instrumentos legais consagrados na legislação e judicialmente reconhecidos, como o ato de indiciamento, legalmente previsto no Código de Processo Penal e reafirmado no artigo $2^{\circ}$ da Lei n. ${ }^{\circ} 12.830 / 2013$, de 20 de Julho, como ato privativo do Delegado de Polícia, materializável por despacho fundamentado, após criteriosa análise técnico-jurídica dos fatos, destinando-se a indicar a autoria vinculando-a a materialidade delitiva ${ }^{35}$. Assim destaco o discurso embutido na Nota n. ${ }^{\circ}$ 4.330/2015 da Procuradoria Geral da República na Ação Direta de Inconstitucionalidade n. ${ }^{\circ}$ 5.073/DF que firma:

Busca o dispositivo conferir ao ato de indiciamento relevância que não possui nem deve possuir, no contexto da investigação criminal e do processo penal. Um inquérito pode transcorrer todo o tempo necessário a apurar a infração e não ter indiciamento ou tê-lo apenas ao final, como éfrequente. Indiciamento é simples registro administrativo da opinião do delegado de polícia, mas não tem reflexos em futura ação penal, pois não vincula o Ministério Público nem o juiz. Alguém indiciado pela polícia pode não ser denunciado pelo Ministério Público, assim como alguém não indiciado pode ser acusado.

34 Conforme observado no Voto Vencido do Ministro Sebastião Reis Júnior da $6^{\circ}$ Turma do Superior Tribunal de Justiça STJ no Recurso Ordinário em Habeas Corpus RHC n. ${ }^{\circ} 201304040602$ - 43356 publicado no DJE 03.02.2015 DTBP, destacando-se que apesar da tese não haver sido acolhida, os sólidos argumentos apresentados pela defesa dificultam o bom andamento da Ação Penal o que no final gerou a ocorrência da prescrição quando do julgado de mérito, propiciando a impunidade.

35 No âmbito do Departamento de Polícia Federal o ato de indiciamento sempre teve que ser fundamentado, conforme se observa na Instrução Normativa n. ${ }^{\circ}$ 11/2001 - DG/DPF Seção X - Do Interrogatório e da Identificação nos Item 89. O auto de qualificação e interrogatório ou qualificação indireta será precedido de despacho fundamentado com a indicação dos pressupostos de fato e de direito e tipificação do delito. 


\begin{abstract}
$[\ldots]$
Ao contrário, a nociva prática de "indiciar" pessoas acarreta prejuizos à investigação e à atividade judiciária, pois (a) gera pecha inútil para o investigado; (b) consome tempo de delegados, que deveriam empregá-lo na investigação, não em inúteis análises jurídicas; (c) acarreta ajuizamento de habeas corpus e outras ações e incidentes, para discutir ato desnecessário, com desperdício de tempo e recursos do Poder Judiciário para processar ejulgar essa inutilidade.
\end{abstract}

O que se pretende aqui é uma nítida concentração de poder, o que tornará o Ministério Público Federal uma instituição opaca à luz e ao controle externo, refratária ao primado da transparência pública e a accountability ${ }^{36}$ da sociedade, uma vez que, (1) no âmbito interno, ao exercer atividade de Polícia Judiciária, estaria exercendo tal função livre de qualquer controle interno, não se submeteria à Corregedoria Geral da Polícia Federal no âmbito da fiscalização funcional e técnica das suas atividades, e (2) no âmbito externo, tal controle não mais existiria por ser o próprio Ministério Público Federal órgão responsável por tal controle, inviabilizando a imparcialidade, pois o autocontrole não é nem moral, nem tampouco, eticamente atingível. Para piorar o cenário, nem o Poder Judiciário poderia exercer o seu controle jurisdicional, por força da Resolução n. ${ }^{\circ}$ 63/2019 de 26 de Junho, que estabelece a tramitação direta dos Inquéritos Policiais entre a Polícia Federal e a Procuradoria da República, a qual se transformaria em uma Instituição livre para escolher o que vai ser investigado, da forma e no prazo que aprouver, e livre de qualquer controle, podendo inclusive manipular e ocultar provas, arquivar procedimentos, em total desrespeito aos primados democráticos e republicanos, retomando assim a seguinte idéia:

A única regra segura num Estado totalitário éque, quanto mais visivel é uma agência governamental, menos poder detém; e, quanto menos se sabe da existência de uma instituição, mais poderosa ela e" (ARENDT, 2000, p. 453)

A concentração de poder transforma uma instituição visível em invisível oculta a sua real intenção, modifica a sua essência de transparente em secreta, desprovida de qualquer controle de forma, torna-a perigosamente imperceptível. Sua atribuição deturpa-se e transforma-se em prejudicial ao bom funcionamento do Estado Democrático de Direito, uma vez que, as interpretações ampliativas contêm, nelas mesmas, o poder da ruptura e devem ser analisadas à luz do direito, sob pena de desvirtuarem com o equilíbrio e a harmonia constitucional dos poderes instituídos, assim:

36 Accountability é um conceito de Ciência Política vinculado a idéia de responsabilização e controle, e configura-se na obrigação dos integrantes de determinado órgão público ou de representação política de prestar contas as instâncias controladoras bem como a população (MELO, 2007: 11-29). 
Os movimentos totalitários têm sido chamados de sociedades secretas montadas à luz do dia. Realmente, embora pouco se saiba quanto à estrutura sociológica e à história mais recente das sociedades secretas, a estrutura dos movimentos, sem precedentes quando comparada com partidos e fações, lembra-nos em primeiro lugar certas caracteristicas dessas sociedades" (ARENDT, 2000, pp. 425-426);

A Polícia Judiciária é uma das instituições com o maior monitoramento de suas atividades uma vez que conta com o controle interno das Corregedorias de Polícia no âmbito da fiscalização funcional e técnica das atividades internas de Polícia Judiciária, e no controle externo efetuado pelo Poder Judiciário no plano procedimental e jurisdicional, bem como do Ministério Público, além dos controles exercidos pelo Tribunal de Contas da União e da Controladoria Geral da União na administração do orçamento institucional, destacando ainda como anseio institucional a matéria que tramita no Congresso Nacional de Proposta de Emenda Constitucional PEC n. ${ }^{\circ}$ 381/2009, para a criação do Conselho Nacional de Polícia ${ }^{37}$.

\section{Desestruturação: esvaziamento de recursos e INVESTIMENTOS}

Identificado os perigos da desconstrução realizada por meio do apoderamento e da usurpação, chegamos à terceira modalidade de antagonismo, a autonomia e independência financeira, manifesta na desestruturação, forma instrumental identificada nos mecanismos de desarticulação institucional como o contingenciamento dos recursos orçamentários de manutenção e investimento no desenvolvimento, inovação e aprimoramento técnico-profissional.

É importante e fundamental deixar claro que não se trata da utilização da autonomia para a obtenção de vantagens corporativistas, mas sim, na proteção institucional, com o objetivo de afastar a incapacitação para o exercício funcional de atribuições legalmente instituídas, por meio de medidas inviabilizadoras do normal exercício das tarefas institucional manifesta no contingenciamento.

37 A Proposta de Emenda Constitucional PEC n. ${ }^{\circ}$ 381/2009 encontra-se em tramitação no Congresso Nacional. Consulta: http://www.camara.gov.br/proposicoesWeb/fichadetramitacao?idProposic ao $=439700$ Consultado em 18.06.2015. 
A autonomia orçamentária é a garantia institucional de elaborar sua proposta orçamentária dentro dos limites estabelecidos na Lei de Diretrizes Orçamentárias (LDO), com fiscalização na alocação dos recursos pelo Tribunal de Constas da União (TCU) e Controladoria Geral da União (CGU), com o fim da correta implementação dos recursos destinados a manutenção e ao desenvolvimento institucional.

Observo que o tema é controverso. A Emenda Constitucional n. ${ }^{\circ}$ 74/2013 concedeu a autonomia para a Defensoria Pública da União, matéria está que vem sendo atacada por meio da Ação Declaratória de Inconstitucionalidade ADI n. ${ }^{\circ}$ 5296, em decorrência de vício de iniciativa na sua propositura, entretanto, o fundamento de concessão de tal medida repousa na necessidade da Defensoria Pública ser dotada de proteção, em razão da importante atividade que exerce, na garantia do acesso dos hipossuficientes no acesso a justiça nos termos do art. $5^{\circ}$ inciso LXXVI da Constituição Federal.

O fundamento jurídico da norma emendada repousa na Defensoria Pública ser a instituição fundamental para a implementação prática da cidadania, possibilitando o acesso a Justiça de parcela considerável da população brasileira e exercício da democracia, conforme Relatório da Comissão de Constituição, Justiça e Cidadania da Câmara dos Deputados pela admissibilidade. ${ }^{38}$

Trata-se do fortalecimento institucional para cumprimento de norma destinada a salvaguarda de preceito constitucional de caráter democrático, o acesso a Justiça é ferramenta indispensável ao hipossuficiente exercer seus direitos e sua cidadania de forma plena e total.

Outras instituições que detém a autonomia, como o Tribunal de Contas da União (TCU), exerce atividade institucional de caráter republicano em defesa da correta aplicação da lei e das instituições de Estado, neste ponto, retomo às questões inicialmente levantadas em relação ao debate político contemporâneo de uma aparente dicotomia entre a realização da Democracia no plano social com o exercício da República de caráter institucional e, reafirmo, que o Departamento de Polícia Federal se insere no contexto político nacional, tanto como órgão de Estado destinado a defesa da demo-

38 Disponível em: http://www.camara.gov.br/proposicoesWeb/prop_mostrarintegra;jsessionid=73C 5B43584F895D900EB16E224D8FE40.proposicoesWeb2 ?codteor=1024216\&filename=Tramitac ao-PEC+207/2012. Consultado em 18.06.2015. 
cracia manifesta no respeito às Liberdades Públicas, Direitos Humanos e no Estado Democrático de Direito, quanto na defesa das Instituições de Estado, patrimônio da União, Sistema Financeiro Nacional, dentre outras atividades eminentemente de salvaguarda da república, devendo, portanto também está protegido pela garantia da autonomia financeira.

\section{Confiança e ACCOUntability}

Argumentos contrários à autonomia do Departamento de Polícia Federal buscam apenas reforçar a retórica da desconstrução manifesta na constante propaganda de desqualificação do trabalho profissional com o objetivo de tornar inviável a realização das suas atribuições legais, a perda de prestígio funcional, instalando-se o anacronismo e a desordem institucional.

A qualidade da democracia e auferível por meio da capacidade de participação do povo na condução do seu país e no desenho de suas políticas públicas, na possibilidade de formular preferências e manifestá-las, tendo por base garantias dentre as quais o acesso e diversidade das fontes de informação (DHAL, 1997, pp 8-9).

$\mathrm{O}$ exato conhecimento das instituições e o acesso às informações corretas de suas atividades é uma importante garantia da democracia, sendo a deturpação das informações e a manipulação das mesmas, ferramentas a serviço do arbítrio das minorias, ou dos governos despóticos e corruptos. As instituições são vetores fundamentais do bom funcionamento do regime democrático, estando fundada na confiança, assim:

A confiança designa a segurança dos procedimentos em face de diferentes circunstâncias que afetam a vida das pessoas. Ela se refere às expectativas que as pessoas alimentam a respeito do comportamento dos outros com quem convivem e interagem; e diz respeito à ação desses outros quanto aos seus interesses, aspirações ou preferências. Nas ciências sociais, o interesse pelo conceito está associado com a preocupação com os processos informais através dos quais as pessoas enfrentam as incertezas e as imprevisibilidades que decorrem da crescente complexificação da vida no contexto de um mundo crescentemente globalizado, interdependente e fortemente condicionado por avanços tecnológicos que afetaram profundamente a comunicação social. Essa situação implica em conhecimento limitado de parte das pessoas comuns quanto aos processos de tomada de decisóes próprios do regime democrático que afetam a sua vida." (MOISES; MENEGUELO; 2013, pp.II-IV) 
A confiança nas instituições democráticas não pode ser considerada como neutra, indeterminada ou genérica, nem tampouco pode ser delimitada pela avaliação do desempenho dos governantes, mas diz respeito propriamente à missão atribuída às instituições para a realização das funções democraticamente atribuídas, embasada nos conteúdos normativos das instituições - a sua justificação relativa aos princípios de liberdade e igualdade e as suas implicações para a estrutura de direitos de cidadania - devendo portanto, assegurar a universalidade, a impessoalidade, a probidade e a justeza de procedimentos no desempenho de sua missão (OFFE, 2001, pp. 73-76).

A democracia é um exercício de equilíbrio entre os legítimos valores a ela concernentes, e a polícia encontra-se inserida nas mesmas dinâmicas de todas as outras instituições governamentais em um contínuo fluxo e refluxo das disputas políticas em um sistema social onde as instituições da republica desempenhar suas atribuições em conformidade com as normas legais e funcionais, em um regime que proíba a sobreposição de uma determinada instituição sobre a outra.

A Polícia Federal como instituição tem papel central na construção da confiança, sendo este o seu elemento central de ação, por ser a instituição depositária das constantes reivindicações de Estado em sua atuação na garantia da ordem pública e paz social, primado do império da lei (LOPES, 2003, p. 309).

As pesquisas voltadas à percepção do trabalho da polícia, genericamente considerada e destinadas à análise do binômio confiança-desconfianças nas instituições de estado, não levam em consideração quando da sua elaboração a diferenciação das atividades de polícia administrativa e judiciária, nem tampouco da esfera de atribuição desta, se federal ou estadual, conforme constatado em pesquisa destinada à aferir a desconfiança política e seus impactos na qualidade da democracia, de foco específico nas causas da desconfiança nas instituições policiais brasileiras, levada a termo entre 2002 e 2007, onde se identificou o importante papel desenvolvido pelo Departamento de Polícia Federal, assim destaco:

O caso da Policia Federal parece bastante singular não apenas por esta instituição apresentar niveis de desconfiança diferentes daqueles das forças policiais estaduais, mas também por pesquisas recentes patrocinadas pela Associação dos Magistrados Brasileiros (AMB) 
apontarem que a Polícia Federal atualmente disputa com as Forças Armadas o posto de instituição pública mais confiável do pais. A partir de uma amostra representativa da população adulta brasileira com acesso à rede telefônica, sondagens realizadas em nome da AMB em 2007 e 2008 mostraram que a Policia Federal detinha a confiança de 75,5\% e 70\% da população, respectivamente. $O$ crescimento vertiginoso da confiança na Polícia Federal entre 2002 e 2007 dificilmentepode ser explicado somente por uma diferença nas amostras e nos métodos de pesquisa usados pela PESB e pela AMB. $A$ reestruturação pela qual passou a Polícia Federal no periodo e $o$ seu maior engajamento no combate aos crimes de colarinho branco, ao lado da imensa visibilidade que adquiriu, certamente são fatores fundamentais para explicar o crescimento da confiança nesta instituição.” (LOPES, 2003, p. 325).

Apesar dessa constatação, ainda hoje as pesquisas de índices de confiança consideram indistintamente dados relativos a atividades policiais preventivas e judiciais de forma conglobadas, e em distintas esferas de poder na federação, ou seja, militar-civil e estadual-federal, mesmo assim, a série histórica do Índice de Confiança Social elaborado pelo Instituto Brasileiro de Opinião Pública e Estatística IBOPE atribui índice 48 em 2014 colocando o conjunto das instituições policiais em primeiro a frente das demais instituições conforme quadro:

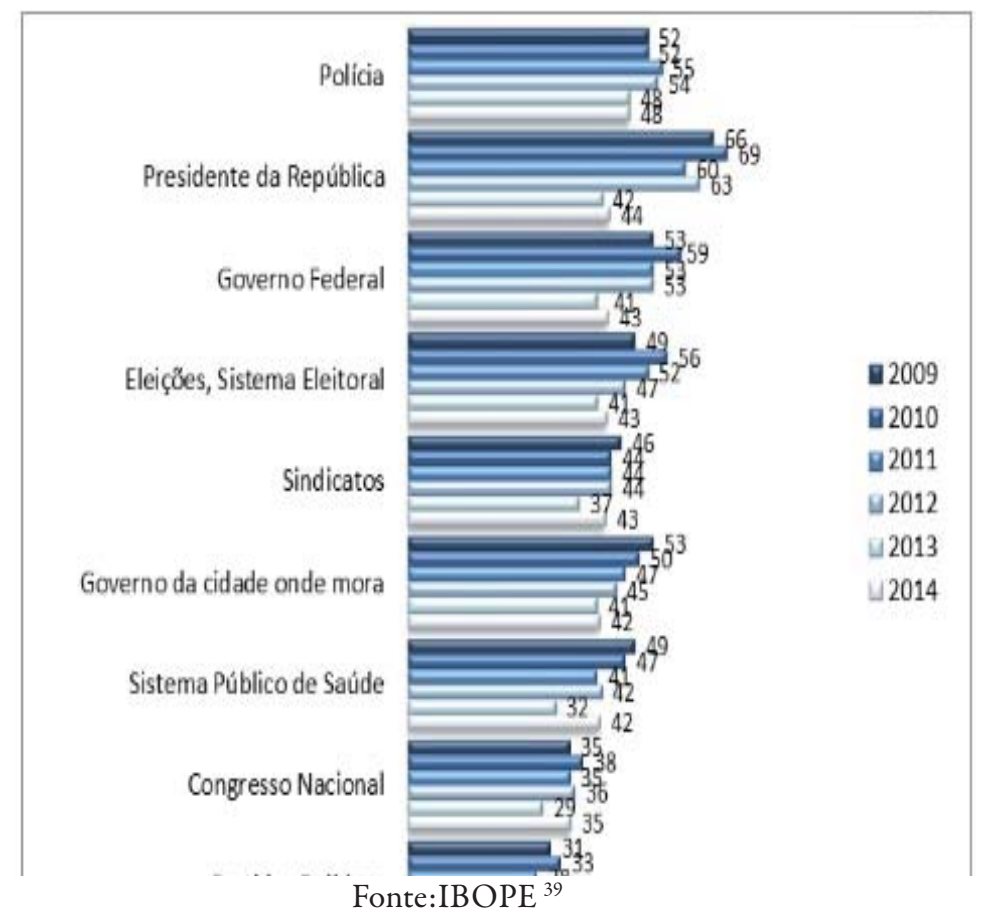

39 Disponível em: http://www.ibope.com.br/pt-br/noticias/Paginas/Ap\%C3\%B3s-queda-acentuadaem-2013,Indice-de-Confianca-Social-se-estabiliza.aspx Visitado em 10 de Junho de 2015. 
As pesquisas de opinião voltadas à percepção do índice de confiança institucional colocam a atividade da Polícia Federal em primeiro lugar, como se observa na pesquisa encomendada pelo Tribunal de Contas do Estado do Rio Grande do Sul (TCE-RS):

$A$ análise dos niveis de confiança dos respondentes nos órgãos públicos, inclusive quanto ao TCE/RS mostra que a instituição com o maior nivel de confiança da população é a Polícia Federal (50\%), seguida pela Defensoria Pública (47\%), TCE/RS (44\%) e Ministério Público (44\%). As instituições com as menores taxas de confiança na amostra foram o Tribunal de Contas da União (14\%), a Assembléia Legislativa (17\%) e a Controladoria e Auditoria Geral do Estado (20\%). (Pesquisa TCE-RS; 2014: 21/22) ${ }^{40}$

A pesquisa do Sistema de Indicadores de Percepção Social (SIPS) elaborada pelo Instituto de Pesquisa Econômica (Ipea) objetivando medir a percepção das pessoas em relação as políticas de segurança públicas, observou que $50,9 \%$ das pessoas entrevistadas responderam que confiam ou confiam muito na Polícia Federal, destacando-se que o levantamento foi feito de forma representativa para todas as regióes do país e publicado em $2012 .{ }^{41}$

As pesquisas representam apenas uma pequena amostra do universo de pesquisas efetuadas sobre segurança pública e destacam o reconhecimento da Polícia Federal como uma instituição capaz de cumprir seu papel na garantia dos direitos civis e políticos, das liberdades públicas e se encontra inserida no modelo democrático de instituição republicana transparente com sólidos mecanismos de controle e avaliação da atuação do por parte da população no desempenho de suas funções.

\section{Conclusão}

A manutenção do perfeito ponto de equilíbrio entre a capacidade de resposta institucional e as demandas impostas ao Departamento de Polícia Federal no desenvolvimento de suas atividades de Polícia Judiciária da União, voltadas à investigação dos crimes cometidos em detrimento dos bens, serviços e interesses

40 Disponível em: http://www1.tce.rs.gov.br/portal/page/portal/tcers/publicacoes/estudos/estudos_ pesquisas/percepcao_sobre_tcers/relatorio_pesquisa_quantitativa_2014.pdf. Visitado em 10 de Junho de 2015.

41 Disponível em: http://www.ipea.gov.br/portal/images/stories/PDFs/SIPS/120705_sips_ segurancapublica.pdf. Visitado em 10 de Junho de 2015. 
da União e, especificamente, no combate a corrupção e desvio de verbas públicas, apresentam a peculiaridade de ter, por muita das vezes, autores e coautores como ocupantes de cargos na alta cúpula dos Poderes da nação, entre os investigados representantes do círculo mais fechado das elites políticas e econômicas.

A crise política, econômica e ética vivenciada pelo Brasil não pode afetar a autonomia das Instituições, sendo imprescindível, neste contexto, o fortalecimento da Polícia Federal como uma instituição eficiente, imparcial e transparente, capaz de cumprir suas missões com a tranquilidade necessária. As três dimensões da autonomia - administrativa, funcional e orçamentária - são os pontos essenciais a serem garantidos para boa qualidade integral da Instituição, caso contrário, haverá a prevalência de suas formas desvirtuadas - o apoderamento, a usurpação e a desestruturação, respectivamente.

Cada Instituição deve cumprir com rigor o seu papel designado pela Constituição Federal e ser estruturalmente bem constituída. A Polícia Judiciária da União, neste contexto, deve ter autonomia administrativa, funcional e financeira, representam os pilares da sustentação de uma instituição republicana, eficiente, isenta e imparcial.

É assim importante inferir medidas de caráter urgente, no plano interno, com a edição de uma Lei Orgânica da Polícia Federal, em conformidade com a Constituição e com os ditames mais modernos da legislação nacional, como as Lei n. ${ }^{\circ} 12.830 / 2013$, n. ${ }^{\circ} 12.850 / 2013$ e n. ${ }^{\circ} 13.047 / 2014$, reativa ao combate as organizaçóes criminosas, reafirmando as prerrogativas e responsabilidades do Delegado de Polícia como Autoridade Policial incumbida da realização de atos de Polícia Judiciária, bem como, no plano externo com a melhoria dos instrumentos de transparência e controle institucional, accountability, com a criação do Conselho Nacional de Polícia (Proposta de Emenda Constitucional PEC n. $\left.{ }^{\circ} 381 / 2009\right)$.

A atual crise brasileira é maior que todos nos, só não pode ser maior que as instituições, apenas com o consenso e a cooperação será possível superá-la, e para isto e importante que todas as instituições da república cumpra o seu papel constitucional, e em estrita obediência aos ditames da lei, na proteção da república e no perfeito exercício da democracia. 


\title{
Guilherme Cunha Werner
}

Delegado de Polícia Federal e Professor Convidado da Academia Nacional de Polícia do Departamento de Polícia Federal (ANP/DPF) nos Cursos de Pós-Graduação e Formação Profissional. Pós-Doutorando em Direito Penal pela Faculdade de Direito da Universidade de São Paulo. Doutor em Ciência

Política pela Faculdade de Filosofia, Letras e Ciências Humana da Universidade de São Paulo USP (2009), onde também detém o título de Mestre em CiênCia Política (2005). Linha de

PESQUISA NA ÁREA DE CORRUPÇÃO E CRIMINALIDADE ORGANIZADA TRANSNACIONAL E SEU IMPACTO NA DEMOCRACIA. Pós-GRAdUaÇão EM Direito Penal Econômico Europeu pelo IDPEE da Universidade

de Coimbra (2002), Bacharel em Direito (1991) e CiênCias Econômicas (1989) pela Pontifícia Universidade Católica de São Paulo (PUC/SP). Foi Delegado da Polícia Civil do Estado DE São Paulo trabalhando no DECAP, DHPP e CORREGEPOL.

É pesquisador do Instituto Superior de CiênCias Policiais e Segurança Interna (ISCPSI) COM SEde em Lisboa/Portugal.

E-MAIL:WERNER.GCW@DPF.GOV.BR

\section{Political exemption in Federal Police}

\begin{abstract}
The aim of this study is to analyze under a renewed perspective the importance of the recognition of autonomy for the Department of the Federal Police in exercising its constitutional function of the Union Judicial Police. From the detailed analysis of the forms of deconstruction of the institutions in a democratic state, systematized in three groups, namely: seizure, usurpation and disruption, build up strong arguments to justify the need to recognize the autonomy in its three dimensions: - administrative, functional and budgetary - in order to pursue the institutional strengthening and its necessary insulation to help overcome problems caused by political, economic and ethical crises in Brazil and thus ensure an independent, republican, efficient, unbiased and impartial procedure. Finally, there is the presentation of suggestion of urgent measures that must be provided to achieve this goal.
\end{abstract}

KEYwORDS: Autonomy, Jurisdiction, Bureaucratic Insulation. Institucional Seizure

\section{Exención Política en la Policía Federal}

\section{RESUMEN}

El objetivo de este estudio es analizar bajo una nueva perspectiva la importancia del reconocimiento de la autonomía para el Departamento de la Policía Federal en el ejercicio de su función constitucional de Policía Judicial de la Unión. A partir del análisis detallado de las 
formas de deconstrucción de las instituciones en un Estado democrático, sistematizados en tres grupos, a saber: la incautación, la usurpación y la desconstrucción; se construye argumentos sólidos para justificar la necesidad de reconocer la autonomía en sus tres dimensiones: administrativa, funcional y presupuestaria - con el fin de obtener el fortalecimiento institucional y su necesario aislamiento para ayudar a superar los problemas causados por las crisis políticas, económicas y éticas en Brasil y así asegurar una actuación independiente, republicana, eficiente e imparcial. Por último, existe la sugerencia de la presentación de medidas urgentes que se deben crear para lograr este objetivo.

Palabras Clave: Autonomía. Jurisdicionalidade. Aislamiento burocrático. Incautación.

\section{REFERENCIAS}

ALMEIDA, Fernanda Dias Menezes de (2013) Competências nas Constituições de 1988. $6^{\circ}$ Ed. São Paulo. Atlas.

ARENDT, Hannah. (2000) Origens do totalitarismo. $4^{\mathrm{a}}$ reimpressão, São Paulo: Companhia das Letras.

ATALIBA, Geraldo. (1984) Instituições de Direito Público e Privado

e República. Tese (Professor Titular) Faculdade de Direito,

Universidade de São Paulo. P.8-9

BUARQUE DE HOLANDA, Sérgio. Raízes do Brasil. 26. ed. São Paulo: Companhia das Letras, 1995, p. 146-147.

CANOTILHO, J. J. GOMES. (1995) Direito Constitucional. Coimbra: Almedina.

CARVALHO, José Murilo de. (1997). Mandonismo, Coronelismo, Clientelismo: Uma Discussão Conceitual. Dados, 40(2) Retrieved July 10, 2015.

CARVALHO, José Murilo de. (2010) A Construção da ordem: teatro das sombras. $5^{\mathrm{a} E d}$. Rio de Janeiro: Civilização Brasileira.

CARVALHO, José Murilo de. (2014) A Cidadania no Brasil. O Longo Caminho. $18^{\mathrm{a}} \mathrm{Ed}$. Rio de Janeiro: Civilização Brasileira.

DAHL, Robert A. (1999) Poliarquia. São Paulo: EDUSP

DAURA, Anderson de Souza e MELO, Cesár Pereira (2011) O Inquérito Policial como Instrumento de Segurança Jurídica: um olhar sobre suas características e finalidades. In. Segurança Pública e 
Cidadania. Brasília, v. 4, n. 2, p. 111-139, jul/dez 2011

DELMAS-MARTY, Michelle (2004) Os Grandes Sistemas de Política Criminal. São Paulo: Manole.

DI PIETRO. Maria Sylvia Zanella. (2001) Direito Administrativo. 13º edição. São Paulo: Saraiva.

FAORO, Raymundo. (2001) Os Donos do Poder. Formação do Patronato Político Brasileiro $3^{\mathrm{a}}$ ed. Globo.

FLORY, Thomas (1986) El Juez de Paz y El Jurado em El Brasil Imperial. Ed. Fundo de Cultura Económica - México

GERMANI, Gino. (1978) Authoritarianism, Facism, and National Populism. New Brunswick: Transaction Books.

HOLLOWAY, Thomas H. Polícia no Rio de Janeiro: repressão e resistência numa cidade do século XIX / Thomas H. Holloway; tradução de Francisco de Castro Azevedo. - Rio de Janeiro: Editora Fundação Getulio Vargas, 1997.

IANI, Octávio. (1973) Populismo y Contradicciones de Classe em Latinoamerica. México: Era.

LEAL, Victor Nunes (2012) Coronelismo, Enxada e Voto: O município e o regime representativo no Brasil. São Paulo: companhia das Letras.

LOPES. Cleber da Silva (2003) Por que os Brasileiros Desconfiam da Polícia? Uma Análise das Causas da Desconfiança na Instituição Policial. In: A Desconfiança Política e Seus Impactos na Qualidade da Democracia. São Paulo: EDUSP.

MATOS, Ilmar Rohloff (1987) O Tempo Saquarema. São Paulo: Hucitec.

MELO, Marcus André. (2007). O viés majoritário na política comparada: responsabilização, desenho institucional e qualidade democrática. Revista Brasileira de Ciências Sociais, 22(63), 11-29.

MOISES, José Álvaro, (2013) Corrupção Política e o Impacto no Brasil Contemporâneo. In: A Desconfiança Política e Seus Impactos na Qualidade da Democracia.

MOISÉS, José Álvaro e MENEGUELLO, Raquel. (2003) Apresentação - A Desconfiança Política e Seus Impactos na Qualidade da Democracia. São Paulo: EDUSP. 
MONET, Jean-Claude (2002) Polícias e Sociedade na Europa. Polícia e Sociedade Vol. 3 São Paulo, Edusp.

NUNES, Edson. (2003) Gramática Política do Brasil: clientelismo e insulamento burocrático. Rio de Janeiro: Jorge Zahar Editor. pp.44-45

OFFE, C. (2001) How can we trust our fellow citizens? In: WARREN, Mark. Democracy and trust. Cambridge: Cambridge University Press.

PEREIRA, Eliomar da Silva (2013) Introdução: Investigação Criminal, Inquérito Policial e Polícia Judiciária. In: Investigação Criminal Conduzida por Delgado de Polícia: Comentários a Lei n. ${ }^{\circ}$

12.830/2013. Curitiba, Ed. Juruá pp. 21-34

PRADO JÚNIOR, Caio. (2008) História Econômica do Brasil. São Paulo, Brasiliense pp.124-128

SAAD, Marta Cristina Cury. (2004) O Direito de defesa no inquérito policial. São Paulo: Revista dos Tribunais.

TAYLOR, I., WALTON, P.; YOUNG, J. (1980) Criminologia Crítica. Rio de Janeiro: Graal.

WEBER, Max (1999) Politik als Beruf. In Gesammelte Politische Schriften von Max Weber Universität Potsdam pp. 369-445.

WEBER, Max (2008) Max Weber's complete writings on academic and political vocations. Ed. Algora Publishing

WERNER, Guilherme Cunha. (2013) Investigação Criminal Conduzida por Delegado de Polícia: Comentários a Lei n. 12.830/2013. Curitiba, Ed. Juruá.

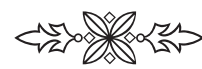

